\title{
Monoamine Oxidase Inhibitors-Revisiting a Therapeutic Principle
}

\author{
Michael Entzeroth, Anil K. Ratty \\ Cennerv Pharma (S) Pte Ltd., Singapore City, Singapore \\ Email: michael@cennervpharma.com
}

How to cite this paper: Entzeroth, M., \& Ratty, A. K. (2017). Monoamine Oxidase Inhibitors-Revisiting a Therapeutic Principle. Open Journal of Depression, 6, 31-68. https://doi.org/10.4236/ojd.2017.62004

Received: December 20, 2016

Accepted: March 31, 2017

Published: April 3, 2017

Copyright $\odot 2017$ by authors and Scientific Research Publishing Inc. This work is licensed under the Creative Commons Attribution International License (CC BY 4.0). http://creativecommons.org/licenses/by/4.0/

\begin{abstract}
Over more than 60 years, monoamine oxidase (MAO) inhibitors are available for therapy of central nervous diseases. Although they have shown to be efficacious specifically in the treatment of major depressive disorders and treatment-resistant depression, they became less a therapeutic choice for the physicians mostly due to severe side effects, such as liver failure and hypertensive crisis associated specifically with the first generation of inhibitors. Nevertheless, this class of drugs is still being used for treatment specifically as more selective and reversible inhibitors became available and will provide clinicians with additional treatment options. The current review revisits monoamine oxidase inhibitors and their potential in the treatment of human diseases, such as anxiety, depression, mood and personality disorders, and pain and introduces current ideas and developments.
\end{abstract}

\section{Keywords}

Monoamine Oxidase Inhibitor, Depression, Alzheimer's Disease, Pain, Phobia

\section{Introduction}

Treatment of psychiatric disorders and specifically depression is an ever growing therapeutic, medical need. Depression is characterized by a persistent depression of mood, lack of interest, impaired cognition and disturbed sleep or appetite. More than 60 years ago, the first class of drugs ever introduced to the market to treat depressive disorders were monoamine oxidase (MAO) inhibitors (Remick \& Froese, 1990). These molecules target two homologous enzymes, monoamine oxidase A (MAO-A) and monoamine oxidase B (MAO-B), differentially expressed throughout the body and brain, both of which are responsible for the oxidative metabolism monoamine neurotransmitters. Three of them, dopamine, norepinephrine and serotonin have been recognized to be key neurotransmitters in the brain (Vogt, 1969) and regulate a number of behavioural patterns and 
motor activity (Blows, 2000; Black et al., 2002; Wise \& Rompre, 1989).

The first clinical results from patients treated with a MAO inhibitor, iproniazid, were very convincing (Castilla del Pino, 1955) and demonstrated that this mechanism of action could be highly effective in the treatment of depression. Some of the early drugs are still being used today. However, the enthusiasm about their efficacy was limited as their use was associated with a number of side effects, among them weight gain, insomnia, withdrawal symptoms, and, more importantly, food-induced hypertensive episodes (Remick \& Froese, 1990; Dilsaver, 1988). Consequently, the introduction of tricyclic antidepressants greatly reduced the use of MAO inhibitors. Several of the new candidates never made it to the market and marketed drugs were discontinued.

Despite these drawbacks, about a handful of MAO inhibitors are still in use. Specifically in the US, where selective and reversible inhibitors such as moclobemide are not available, they are used as third or fourth level treatment of depression (Wimbiscus, Kostenko, \& Malone, 2010) and show efficacy in the management of certain subtypes of depression. More recent research developments have resulted in candidates with the promise of a better safety profile and widening of their therapeutic application. There is an increasing call among physicians for safer MAO inhibitors as they have been found to not only improve the melancholy in depression but also improve cognition and mood in this disease (Delumeau et al., 1994). There is the medical need providing physicians with an additional option to manage treatment resistant patients.

It is the objective of this review, to outline the development of monoamine inhibitors, describe the different classes and introduce novel developments. We also like to cover the risks and the potential of MAO inhibitors in the treatment of different, mostly CNS diseases. The significance of MAO inhibitors for the treatment of psychiatric diseases is outlined in Figure 1. Unlike tricyclic antidepressants, MAO inhibitors increase the levels of all three neurotransmitters, dopamine, norepinephrine and serotonin, in the brain and thereby regulate different aspects of behaviour, cognition, motivation, and mood.

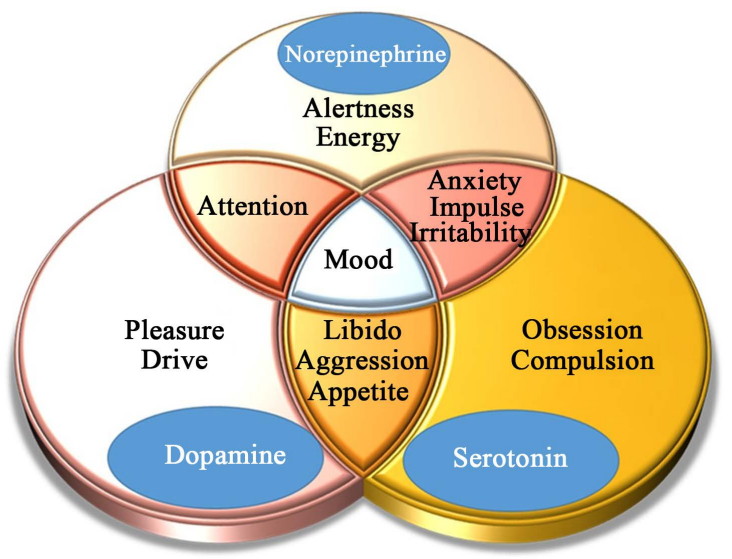

Figure 1. The effects of neurotransmitters, dopamine, norepinephrine and serotonin, in the brain on different behavioural patterns. All three neurotransmitters are elevated under MAO inhibitor treatment 


\section{MAO Inhibitors}

\subsection{The Beginning of MAO Inhibitors}

MAO inhibitors (Figure 2) were the first category of drugs developed for the treatment of depression. Iproniazid, also known as Marsilid, Rivivol, Euphozid, Iprazid, Ipronid, Ipronin, is the first clinically effective MAO inhibitor and the first antidepressant ever marketed. It doesn't discriminate between MAO-A and MAO-B. Iproniazid is a derivative of isoniazid, an antibiotic used in the treatment of tuberculosis (TB), was studied in this indication in the early 1950s. While iproniazid shows activity in TB infected mice and in TB patients, it was serendipitous to observe that patients treated during the trial reported some unusual side effects: sunnier moods and increased interest in pleasurable activities. These patients also reported weight gain and an improvement in mood (Castilla del Pino, 1955). In 1952, a research team at the Northwestern University Medical School, led by Ernst Albert Zeller demonstrated that ipronazid was capable of inhibiting MAO (Zeller, Barsky, Fouts, \& Kirchheimer, 1952). Subsequent work by Loomer, Saunders and Kline demonstrated that withdrawn patients responded well to ipronazid and described it as the first drug to "energize" rather than to sedate patients suffering from depression (Loomer, Saunders, \& Kline, 1957). This effect was later also referred as "marsilization" following the tradename of the drug, Marsilid (Chessin, Dubnick, Kramer, \& Scott, 1957). In 1958, iproniazid (Marsilid) was brought to the market by Roche (Basel, Switzerland) as the first MAO inhibitor for the treatment of depression and initiated the development of a number of MAO inhibitors (Himmelhoch, 1995). However, only three years later, the drug was withdrawn from the market in most of the countries as it was taken responsible for unacceptable incidence of hepatitis and kidney damage (Kline, 1970; Kline \& Cooper, 1980; Visfeldt, 1961).

Subsequently, six classes of drugs, inhibiting the MAO enzymes were developed:

-Irreversible, non-selective MAO inhibitors;

-Irreversible, selective MAO-A inhibitors;

-Irreversible, selective MAO-B inhibitors;

-Reversible, non-selective MAO inhibitors;

-Reversible, selective MAO-A inhibitors (RIMA);

-Reversible, selective MAO-B inhibitors.

Irreversible in this context means that the inhibitor covalently binds to the enzyme and can no longer dissociate from the binding site while the reversible inhibitor binds in a non-covalent manner to the enzyme and is able to dissociate over time. Non-selective describes that the inhibitor is binding with similar affinity to both, MAO-A and MAO-Benzymes, while selective inhibitor bind with higher affinity to one of the subtypes.

The initial MAO inhibitors were non-selective for either of the subtypes, MAO-A or MAO-B, and, in addition, bound irreversibly to the target enzyme. Despite their activity in the treatment of disease, both of these activities provoked side effects and made them difficult to handle by the clinicians. The 


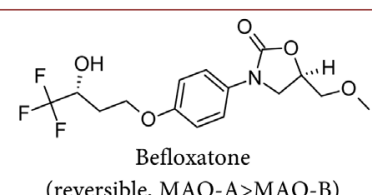

(reversible, MAO-A $>\mathrm{MAO}-\mathrm{B}$ )<smiles>NC(=O)CN1Cc2ccccc2OC1=O</smiles>

Caroxazone

(reversible, $\mathrm{MAO}-\mathrm{A} \approx \mathrm{MAO}-\mathrm{B}$ )<smiles>C#CCN(C)CCCOc1ccc(Cl)cc1Cl</smiles>

(irreversible, $\mathrm{MAO}-\mathrm{A}>\mathrm{MAO}-\mathrm{B}$ )

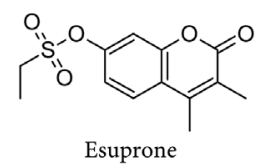

(reversible, $\mathrm{MAO}-\mathrm{A}>\mathrm{MAO}-\mathrm{B}$ )

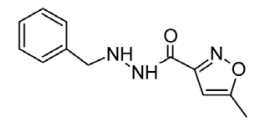

Isocarboxazide (irreversible, $\mathrm{MAO}-\mathrm{A} \approx \mathrm{MAO}-\mathrm{B}$ )

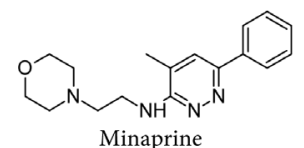

(reversible, $\mathrm{MAO}-\mathrm{A}<\mathrm{MAO}-\mathrm{B}$ )<smiles>NNCCc1ccccc1</smiles>

(irreversible, $\mathrm{MAO}-\mathrm{A} \approx \mathrm{MAO}-\mathrm{B}$ )

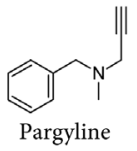

(irreversible, $\mathrm{MAO}-\mathrm{A}<\mathrm{MAO}-\mathrm{B}$ )

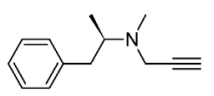

Selegiline (irreversible, $\mathrm{MAO}-\mathrm{A}<\mathrm{MAO}-\mathrm{B}$ )

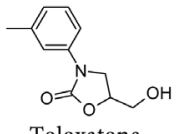

Toloxatone

(reversible, MAO-A $>$ MAO-B)

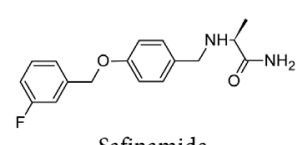

Safinamide

(reversible, MAO-A $<$ MAO-B)

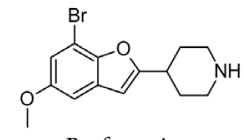

Brofaromine

(reversible, MAO-A $>$ MAO-B)

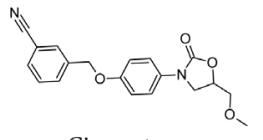

Cimoxatone

(reversible, $\mathrm{MAO}-\mathrm{A}>\mathrm{MAO}-\mathrm{B}$ )

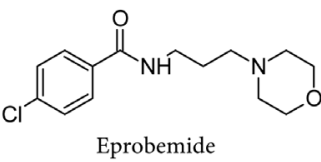

(reversible, $\mathrm{MAO}-\mathrm{A}>\mathrm{MAO}-\mathrm{B}$ )

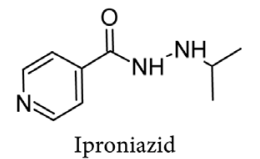

(irreversible, $\mathrm{MAO}-\mathrm{A} \approx \mathrm{MAO}-\mathrm{B}$ )

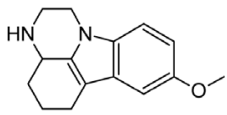

Metraindol

(reversible, MAO-A $>$ MAO-B)

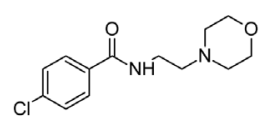

Moclobemide (reversible, $\mathrm{MAO}-\mathrm{A}>\mathrm{MAO}-\mathrm{B}$ )

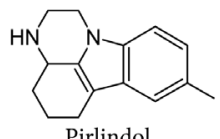

(reversible, $\mathrm{MAO}-\mathrm{A}>\mathrm{MAO}-\mathrm{B}$ )

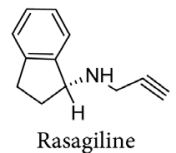

(irreversible, $\mathrm{MAO}-\mathrm{A}<\mathrm{MAO}-\mathrm{B}$ )

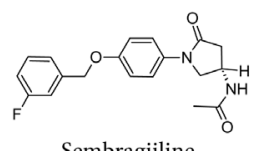

Sembragiiline

(irreversible, $\mathrm{MAO}-\mathrm{A}<\mathrm{MAO}-\mathrm{B}$ )

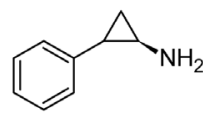

Tranylcypromine (irreversible, $\mathrm{MAO}-\mathrm{A} \approx \mathrm{MAO}-\mathrm{B}$ )

Figure 2. Structure of some MAO mentioned in the review. 
efforts to improve the drug properties finally resulted in the discovery of subtype-selective and reversible inhibitors of which some of them are currently still investigated in the clinics.

\subsection{Irreversible, Non-Selective MAO Inhibitors}

Iproniazid belongs to the hydrazine class of MAO inhibitors (Figure 2) and binds irreversibly to the enzyme. Other hydrazine inhibitors were subsequently developed and include isocarboxazide (Marplan) (Heinrich \& Petrilowitch, 1960; Larsen \& Rafaelsen, 1980) and phenelzine (Nardil) (Saunders, Roukema, Kline, \& Bailey, 1959; Furst, 1959). More than ten other hydrazine MAO inhibitors, including benmoxin (Neuralex, Nerusil), iproclozide (Sursum), mebanazine (Actomol), niamid (Nialamide), octamoxin (Ximaol/Nimaol), pheniprazine (Cantron), phenoxypropazine (Drazine), pivalylbenzhydrazine or pivhydrazine (Tresavid), and safrazine (Safra), have been either withdrawn from the market or were never registered for commercialization, mostly because of hepatotoxicity.

Originally synthesized as an amphetamine-mimetic in the 1940s, tranylcypromine (Parnate) was the first non-hydrazine MAO inhibitor discovered in 1959 (Tedeshi et al., 1959). It was brought to the market in the United Kingdom in 1961 by Smith, Kline \& French and later introduced in the United States (US) (Shorter, 2008). However, only three years later it was withdrawn from the market following a number of patient deaths caused by intracranial bleeding and hypertensive crisis (Dorrell, 1963; Blackwell, 1963).

The fact that tranylcypromine was reintroduced in 1964 to the market and is still used in the clinic underlines that MAO inhibitors are valuable medication for the treatment of depression. However, despite their excellent efficacy and the fact that they had a game-changing effect on the quality of life of the patients, the toxicity and increase in blood pressure rendered a bad reputation to MAO inhibitors. And after the introduction of tricyclic antidepressants, all MAO inhibitors only played a limited role in the clinics. On the research side, the safety concerns and need for MAO inhibitors triggered the search for novel candidates with an increased safety profile.

\subsection{Irreversible, Selective MAO-A Inhibitors}

Clorgiline was the first MAO-A-selective inhibitor and irreversibly interacts with the enzyme (Youdim, 1975). Its structure is closely related to pargyline which has a slight selectivity for MAO-B. The reason for this difference in selectivity can be explained by the 3-dimentional structure of the enzymes and caused by the structural differences arising from Ile-335 in MAO-A versus Tyr-326 in MAO constraining the access to the active centre and limiting the access of clorgiline (Son, 2008). Clorgiline was never marketed but used as tool in scientific research and further search for selective MAO-A inhibitors finally cumulate in the discovery of reversible and selective inhibitors of MAO-A also known as RIMAs. 


\subsection{Irreversible, Selective MAO-B Inhibitors}

Together with clorgiline its structural congener, pargyline (Eutonyl) was discovered and subsequently developed as an antihypertensive (Pray, 2007). Its effect is believed to be mediated by the inhibition of norepinephrine deamination. Pargyline was brought to the market in the US and UK by Abbott in 1963 (Bryant et al., 1961) but was discontinued in 2007mainly because it triggered hypertension when taken together with certain foods. Individuals treated with pargyline must avoid concurrent consumption of tyramine-containing foods such as blue cheese and beer, as this can lead to a hypertensive crisis.

Inhibition of MAO-B leads to an increase in dopamine and this has triggered interest for inhibitors of this subtype for the treatment of Parkinson's disease (PD) (Riederer \& Lau, 2011; Henchcliffe, Schumacher, \& Burgut, 2005; Fernandez \& Chen, 2007). Selegiline (Eldepryl, Zalapar, E-250), also known as (-)-deprenyl, and Rasagiline (Azilect) are both selective and irreversible inhibitors of MAO-B. The history of selegiline goes back to the 1960s when Jŏzsef Knoll, a Hungarian scientist at the Semmelweis University in Budapest, synthesized E-250 which was later named selegiline and Knoll subsequently developed the (-)-enantiomer (Knoll \& Magyar, 1972; Knoll \& Magyar, 1977). Data of the first clinical trial with selegiline in patients suffering from depression demonstrated positive effects (Varga \& Tringer, 1967). Later, the DATATOP multi-center clinical trial (US, Canada) involving 23 University Institutions, proved that the treatment of newly-diagnosed Parkinson patients with selegiline significantly delayed the need for levodopa therapy (Tetrud \& Langsto, 1989). Rasagiline was first patented (US3, 513, 244) in 1970 as an antihypertensive by Aspro Nicolas Limited in London, United Kingdom. Later, Teva Pharmaceuticals Inc. in collaboration with the Technion, both in Israel, investigated the enantiomers of the compound in search for drugs with similar efficacy as selegiline and found the R-enantiomer carrying its dopamine potentiating and possible neuroprotective activity suitable for the treatment of Parkinson's disease (Finberg, Lamensdorf, Commissiong, \& Youdim, 1996). In the US, Selegiline was registered with the Food and Drug Administration (FDA) in 1996 following an application by Summerset Pharmaceurticals (US) which, while the application was under review was acquired by two generic companies, Mylan and Bolan Pharmaceuticals, both US-based. Rasagiline was approved for the treatment of PDin Europe in 2005 and by the US-FDA in 2006 (Shapira, Bate, \& Kirkpatrick, 2005; Knudsen-Gerber, 2011). Both drugs have been shown to possess neuroprotective activities in cell culture and in-vivo models (Ama, Tamar Amita, \& Youdim, 2004). They are prescribed today either as first line treatment in early PDor as add-on when patients require levodopa (L-DOPA) treatment.

\subsection{Reversible, Non-Selective MAO Inhibitors}

In search for reversible MAO inhibitors, caroxazone (Surodil, Timostenil) was developed in 1978 by Farmitalia (Italy). The drug was a reversible short-acting non-selective MAO inhibitor and when tested in patients suffering from depres- 
sion the drug was effective and well tolerated (Checchini et al., 1978). In a subsequent tyramine challenge, caroxazone resulted in a blood pressure response and tyramine-poor diet was recommended for patients during caroxazone treatment, however, is no longer on the market (Martini et al. 1981).

\subsection{Reversible, Selective MAO-A Inhibitors (RIMA)}

More subtype-selective MAO inhibitors seemed to be required and subsequent research led to the discovery of reversible, selective inhibitors of monoamine oxidase A (RIMAs). Moclobemide (Ro 11-1167, Amira, Aurorix, Clobemix, Depnil and Manerix) is a prototype example of a RIMA. Moclobemide was synthesized initially by Pierre-Charles Wyss, a scientist at Roche laboratories in Basel (Switzerland), as part of a discovery program for anti-hyperlipidemics. Failing to demonstrate the desired activity it was subsequently discovered that moclobemide inhibited MAO and subsequently developed as an antidepressant (Haefely et al., 1992). With $\mathrm{IC}_{50}$-values of $6 \mu \mathrm{M}$ and $>1,000 \mu \mathrm{M}$ for MAO-A and $\mathrm{MAO}-\mathrm{B}$ in rat brain preparations, moclobemide was a relatively weak but highly selective inhibitor (Da Prada et al., 1989; Kettler, Da Prada, \& Burkard, 1990). In-vivo experiments in rodents, however, revealed that moclobemide also inhibited MAO-B to a substantial level which was later explained by the formation of an active metabolite (Ro 16-6491) with reduced selectivity and increased activity towards MAO-B. This metabolite is not formed in humans (Schoerlin \& Da Prada, 1990). Moclobemide is relatively short acting with inhibition of MAO usually between 8 and 10 hours (Nair, Ahmed, \& Kin, 1993). Even though it was never introduced into the US, moclobemide has been used successfully in other parts of the world (Chen \& Ruch, 1993). In most countries, still selective serotonin reuptake inhibitors (SSRIs) were first-line treatments, except for Finland and Australia where moclobemide is widely used as first antidepressant therapy (Lotufo-Neto, Trivedi \& Thase, 1999). Moclobemide is in use in many countries and is typically prescribed in the range of 300 to $450 \mathrm{mg} /$ day with optimal benefit in some patients at doses of greater or equal to $900 \mathrm{mg} /$ day. The use of moclobemide is very safe and patients treated with the drug are rarely affected by hypertensive crisis and it requires approximately eight times more tyramine (63 $\mathrm{mg}$ ) as compared to tranylcypromine (8 $\mathrm{mg}$ of tyramine) (Laux, Volz, \& Möller, 1995). Letufo-Neto et al., 1993, described mocloblemide in comparison with another RIMA, brofaromine initially developed by Ciba-Geigy (Switzerland), as more effective compared to SSRIs based on the results from 8 clinical studies. Both moclobemide and brofaromine had a safety profile similar to SSRIs. Despite these data, brofaromine was discontinued following the merger between Ciba-Geigy and Sandoz into Novartis (Switzerland) for purely commercial reasons (Miner, Conner, \& Davidson, 2000).

Eprobemide (Befor) differs from moclobemide only by a single methylene group in the side chain of the 4-chlorobenzamide. It is a non-competitive reversible inhibitor of monoamine oxidase A and was marketed in Russia between 1987 and 2003 (Befol-4DOKTOR. RU Drug Information Handbook). Pirlindol 
(Lifril) and its structurally related metraindol (Inkazan) are two further reversible MAO-A inhibitors developed for the Russian market (Mashkovsky \& Andrejeva, 1981; Shvedov et al., 1972). Pirlindole inhibits the neuronal uptake of noradrenaline and exerts reversible, short-lasting anti-MAO activity.

Among the early RIMAs were also the class of aryl oxazolidinones. This class of compounds gave rise for a variety of MAO inhibitors, reversible or irreversible inhibitors of the A or B form of MAO (Strolin Benedetti \& Dostert, 1987). Examples are cimoxatone (MD780515) and toloxatone (Humoryl) which was in 1985 introduced as to the market in France (Wouters, 1998). Cimoxatone was never registered for the market as it caused a tyramine pressure response comparable to the irreversible inhibitor clorgyline (Emilien, 1999). Befloxatone (Consonar, MD370, 503), another MAO-A selective inhibitor of the same class with a high affinity for MAO-A (2 nM), was developed in the 1990s for the treatment of depression by Synthelabo (France) (Patat et al., 1995; Curet, 1996). Befloxatone was investigated on its interaction with tyramine and its effect on blood pressure. However, dietary restrictions were found to be unnecessary when the drug was given in a regimen of up to $20-\mathrm{mg}$ once daily after meals (Nair, Ahmed, \& Kin, 1993). Following the merger between Sanofi (France) and Synthelabo in 1999, befloxatone was discontinued despite encouraging clinical results (Sadock, Sadock, \& Sussman, 2014).

Another RIMA, minaprine (Brantur, Cantor, Agr 1240) was discovered by Laborit in the late 1960s and described as "l'inhibiteur de l'inhibition (inhibitor of the inhibition)". It was later found that minaprine behaved like a specific and short acting MAO-A inhibitor (Kan, Mouget-Goniot, \& Biziere, 1986). Even though minaprine was highly effective in depressed patients based on $50 \%$ reduction in the Hamilton Depression Rating Scale and was used throughout France until 1996, it was eventually withdrawn as it was reported to cause seizures (Montgomery et al., 1991; Fung et al., 2001).

\subsection{Reversible, Selective MAO-B Inhibitors}

Safinamide (Xadago) is an oral $\alpha$-aminoamide derivative developed by Newron (Italy) for the treatment of PD (Deeks, 2015). Safinamide modulates dopamine levels through its action as a highly selective and reversible MAO-B inhibitor but also acts via sodium channel blockade and calcium channel modulation. It is approved in the European Union (EU) and some non-EU countries. The regulatory approval in the US is pending.

\subsection{Further Developments}

The encouraging therapeutic effects of reversible, selective and competitive MAO inhibitors has prompted some industrial players to look for novel, well-tolerable drug candidates with no tyramine pressure response. The economic potential is greatest in the US where RIMAs such as moclobemide are not available. However, many of the attempts have not succeeded. Esuprone (LU43839), a MAO-A inhibitor, was initially developed by Knoll AG in Lud- 
wigshafen (Germany) but dropped in 1996 (Schlecker et al., 1984; Rendenbach-Mueller, Schlecker, Traut, \& Weifenbach, 1994; Esuprone. AdisInsights: http://adisinsight.springer.com/drugs/800005281). The only MAO-A inhibitor currently in development is CB2202 (TriRima ${ }^{\mathrm{mm}}$ ), aka CX157 or KP157 (Figure 3). The drug candidate is a highly selective MAO-A inhibitor $\left(\mathrm{IC}_{50}=3.3 \mathrm{nM}\right.$ in human brain) with no apparent affinity for the MAO-B subtype (Fowler et al., 2010). Thereby CB2202 is more than 100-times more potent than moclobemide inhibiting MAO-A. Binding to human brain MAO-A is reversible as shown in a PET scan study using $\left[{ }^{11} \mathrm{C}\right]$-clorgyline as a radiotracer [Figure 4]. Plasma levels correlated well with brain MAO-A occupancy. As CB2202 is highly selective for MAO-A, MAO-B remains available to metabolize tyramine taken up with the diet and to prevent hypertension. The pressor effect of tyramine during CB2202 treatment was evaluated in a clinical study (Figure 5) (Burch et al., 2014) which concluded that the data obtained withCB2202 provide an adequate margin of safety with respect to tyramine interaction, suggesting that future studies can be conducted without the need for dietary tyramine restrictions. Subsequently, CB2202 was investigated in two Phase II studies in treatment-resistant depression (TRD) and major depressive disorders (MDD, NCT00739908), however, the results were compromised by non-compliance and a high placebo effect (Tagum, 2014). In 2011, a patent on a new modified release form was published (WO2011096953A1) to improve compliance and a new trial design is currently evaluated to limit the placebo effect in an upcoming pivotal trial. CB2202, a reversible, selective MAO-A inhibitor, could provide physicians with another<smiles>O=S1(=O)c2ccc(F)cc2Oc2cc(OCC(F)(F)F)ccc21</smiles>

Figure 3. Chemical structure of CB2202 (TriRima ${ }^{\mathrm{m}}$ ), previously KP157, CX157, 3-fluoro7-(2,2,2-trifluoroethoxy)-phenoxathiin-10,10-dioxide.
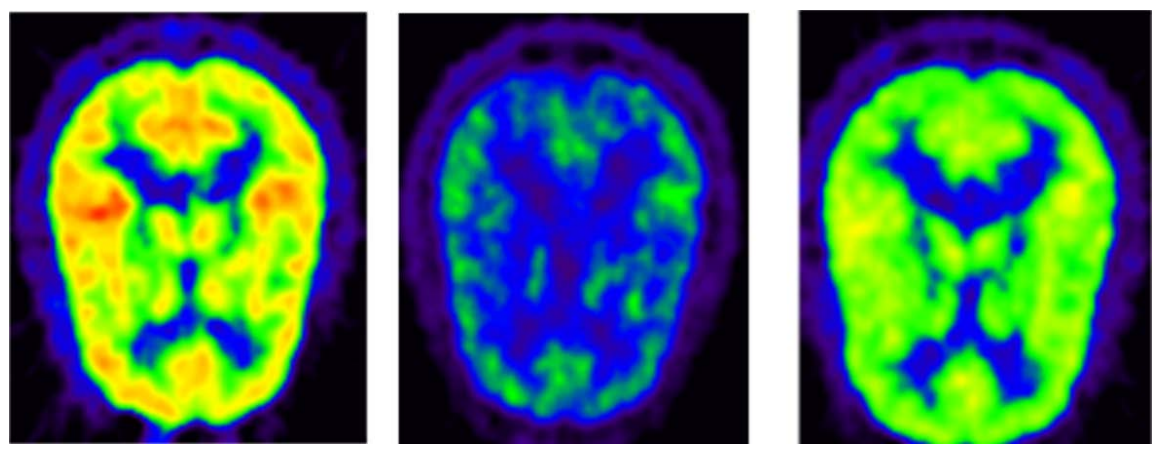

Figure 4. PET study demonstrates brain penetration and reversible MAO-A Inhibition by CB2202. Binding of ${ }^{11} \mathrm{C}$-Clorgiline, an ${ }^{11} \mathrm{C}$-labelled form of an irreversible, selective MAO-A inhibitor, at baseline, 2 hours and 12 hours after CB2202 60 mg p.o. determined via PET brain imaging (Reproduced from Burch et al., 2014). 


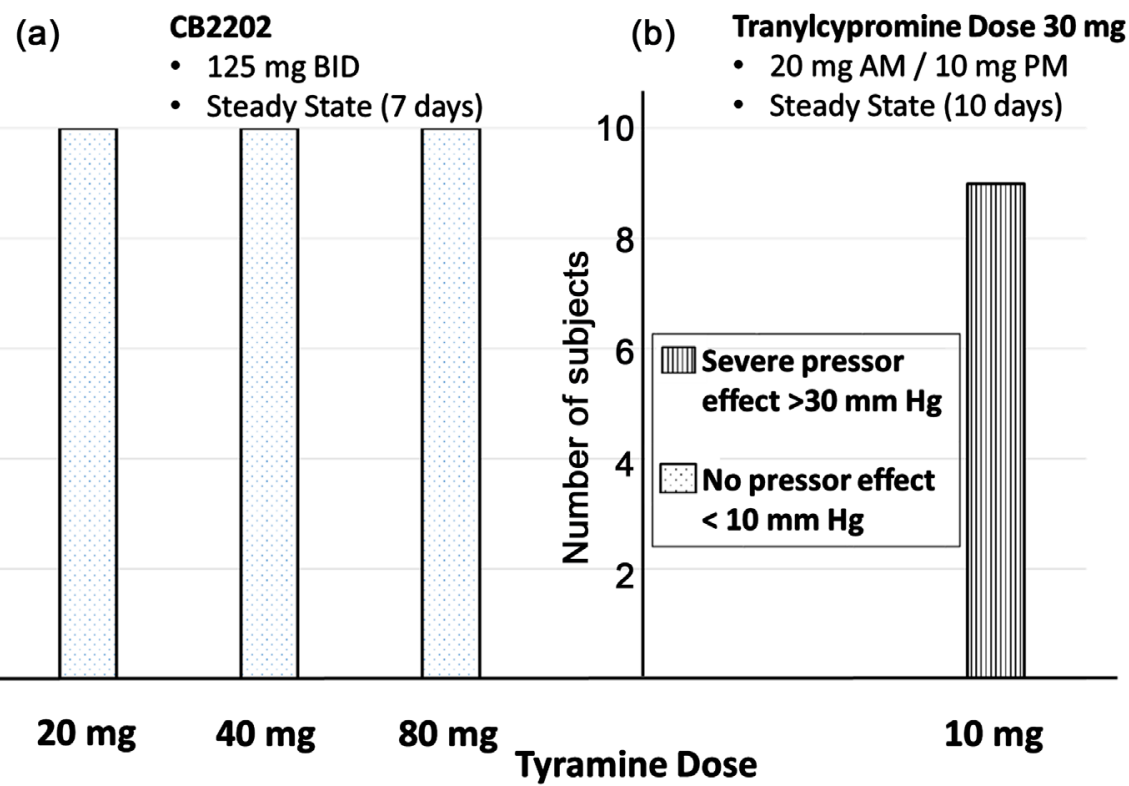

Figure 5. Individual tyramine pressor response on medication. (a) After 7 days of twice daily dosing with $125 \mathrm{mg} \mathrm{CB} 2202$, no pressor effect was observed in any of the 10 subjects upon administration of up to $80 \mathrm{mg}$ of tyramine; (b) After 10 days dosing subjects with $20 \mathrm{mg}$ tranylcypromine in the morning and $10 \mathrm{mg}$ in the afternoon, all 9 subjects experienced a severe pressor effect upon administration of $10 \mathrm{mg}$ tyramine.

treatment alternative for patients who failed to respond to other treatment options (Lum \& Stahl, 2012).

Among the selective MAO-B inhibitors, sembragiline (EVT302, RG1577, Ro4602522) has been evaluated for the treatment of Alzheimer's Disease (AD). The drug was licensed by Evotec AG (Hamburg, Germany) to Roche AG (Basel, Schwitzerland) and its Japanese subsidiary Chugai (Tokyo, Japan). Evotec, in June 2015, published in a press release that sembragiline had missed the primary endpointand failed to demonstrate benefit on the primary endpoint (Alzheimer's Disease Assessment Scale-Cognitive Behaviour Subscale, ADAS-cog-11) after 52 weeks of treatment (Evotec, press release, 30 June 2015)

https://www.evotec.com/uploads/cms_article/2739/PR_2015-06-30_Roche_e.pdf.

Roche is currently analysing the outcome for the other endpoints to come up with a decision whether to pursue the development.

\section{Adverse Effects of MAO Inhibitors}

\subsection{Hypertensive Crises}

The major issue with the use of the first generation of MAO inhibitors was the development of high blood pressure that could mount to a hypertensive crisis. When tranylcypromine resulted in deaths caused by intracranial bleeding and hypertensive crisis (Dorrell, 1963; Blackwell, 1963), research tried to find the causes. It was observed that cheese consumption was related to severe increases in blood pressure following treatment with tranylcypromine (Miller, 1963; Marks, 1965). Subsequently, Blackwell and Marley identified increased levels of 
tyramine in blood samples in MAO inhibitor-treated animals and correlated them with a sympathomimetic stimulus and blood pressure increase (Blackwell \& Marley, 1966). The blood pressure increase induced by cheese products was inherent, even though to different extents and time-course, in all inhibitors of this first generation (Blackwell \& Marley, 1964). "Cheese effect" became a synonym for this side effect (Sandler, Glover, Ashford, \& Esmail, 1980; Anderson, Hasan, McCrodden, \& Tipton, 1993). Based on these findings, the Council on Drugs published a revised monograph on tranylcypromine with more limited indications for its use, precautions to be taken (Atchley, 1964) and permitted its further use. The knowledge on the inhibition of tyramine metabolism and the resultant blood pressure increase resulted in the definition of meal plan focused on foods that have low amounts of tyramine to be maintained during monoamine inhibitor therapy. Tyramine is found in aged foods and fermented foods (Folks, 1983). The foods to avoid are listed in Table 1.

\subsection{Serotonin Syndrome}

Besides the already mentioned hypertensive crisis induced by tyramine containing food, MAO inhibitors cannot be combined with other agents which increase serotonin levels in the synapses such as selective serotonin reuptake inhibitors (SSRIs). Such combination may result in excessive serotonin levels, a hyper-stimulation of serotonin receptors and the potentially fatal "serotonin syndrome" or serotonin toxicity (Dvir \& Smallwood, 2008; Gillman, 2007). On the mild side, serotonin toxicity can cause agitation, confusion, migraines, and myoclonus, while in severe cases coma, cardiovascular collapse, hyperthermia, permanent hyperthermic brain damage, seizures, and even death can be observed

Table 1. MAO inhibitor diet.

\begin{tabular}{|c|c|c|}
\hline Food type & Foods to be avoided & Foods allowed \\
\hline \multirow[t]{2}{*}{ Cheese } & All matured or aged cheese & $\begin{array}{l}\text { Fresh cottage cheese, ricotta cheese, cream cheese, } \\
\text { and processed cheese slices }\end{array}$ \\
\hline & Casseroles made with these cheeses (e.g., lasagne). & Fresh milk products. (e.g., sour cream, ice cream, yogurt) \\
\hline \multirow[t]{3}{*}{ Meat } & $\begin{array}{c}\text { Fermented/dry sausage (e.g., pepperoni, mortadella } \\
\text { salami, summer sausage) }\end{array}$ & $\begin{array}{l}\text { All fresh packaged or processed meat such as hot dogs, } \\
\text { fish, or poultry: store in refrigerator immediately } \\
\text { and eat as soon as possible. }\end{array}$ \\
\hline & Improperly stored meat, fish, or poultry & \\
\hline & Improperly stored pickled herring & \\
\hline Fruits \& vegetables & Fava or broad bean pods (not beans) & Banana pulp \\
\hline Beverages & Tap (draft) beer & $\begin{array}{l}\text { Alcohol: no more than two bottled or canned beers } \\
\text { or two } 4 \text {-ounce glasses of wine per day }\end{array}$ \\
\hline \multirow[t]{3}{*}{ Miscellaneous } & Marmite concentrated yeast extract & Other yeast extract (e.g., Brewer's yeast) \\
\hline & Sauerkraut & Pizzas without aged cheeses \\
\hline & Soy sauce or other soy bean condiments & Tofu, soy milk \\
\hline
\end{tabular}


(Sun-Edelstein, Tepper, \& Shapiro, 2008). Caution is advised when switching MAO inhibitors to serotonergic antidepressants and vice versa (Hughes, 2001). It is advised to wait for at least 14 days when switching from a MAO inhibitor to a serotonergic antidepressant. Moving from a SSNR to a MAO inhibitor, a waiting time of 5 half-life periods is recommend adding to 5 - 7 days before commencing the MAO inhibitor. Due to its long half-life fluoxetine, a SSRI, should be discontinued for at least 5 weeks (Grady \& Stahl, 2012). In the same context, MAO inhibitors should not be combined with stimulants, noradrenergic agents and tricyclic antidepressants as they might increase noradrenalin levels and may cause a raise in blood pressure (Grady \& Stahl, 2012; Feighner, Herbstein, \& Damlouji, 1985). Similarly, all drugs affecting noradrenalin transporters come with the risk of causing an increase in blood pressure.

\subsection{Drug-Drug Interactions}

Another important consideration for the use of MAO inhibitors is drug-drug interactions their metabolism can involve different isoforms of cytochrome P450-dependent enzymes as many other drug classes. As an example given, moclobemide appears to affect several isoenzymes (CYP2C19, CYP2D6 and CYP1A2) (Baker, Urichuk, McKenna, \& Kennedy, 1999; Mayersohn \& Guentert, 1995). The doses of moclobemide need to be reduced in patients who require cimetidine pharmacotherapy as cimetidine reduces the clearance of moclobemide (Krishnan, 2013). Cimetidine therapy is expected to approximately double moclobemide steady-state concentrations. Moclobemide is well tolerated and cases of death reported have been attributed to suicides rather than drug toxicity (Giroud et al., 2004; Hernandez, Montero, Pla, \& Villanueva, 1995).

\subsection{Withdrawal Phenomena}

Discontinuation of MAO inhibitors, specifically tranylcypromine and phenelzine, has been reported to cause withdrawal phenomena specifically when they were used in high doses (Bellon \& Coverdale, 2009; Dilsaver, 1988). The withdrawal phenomena are, among others, agitation, aggressiveness, cognitive impairment, insomnia, paranoid delusions and slurred speech. These effects were compared to amphetamine specifically because tranylcypromine is structurally related to amphetamine. Further, MAO inhibitors down-regulate sympathomimetic receptors in humans (Siever, Uhde, \& Murphy, 1982) reducing the catecholamine output. Psychotropic drugs should be therefore discontinued.

Two other cases were described (Shaikh \& Fuls, 2009; Bellon \& Coverdale, 2009) where patients of patients exhibiting signs of agitation and psychotic symptoms can be rationalized differently as these patients also exhibited signs of thrombocytopenia and changes in liver enzymes. These patients had a history of misuse of MAO inhibitors and overdosed the drugs to experience a euphoric state. Clinicians are advised to inform patients about a potential addictive potential (Bellon \& Coverdale, 2009).

It is worth to note that the selective and reversible MAO inhibitor molobe- 
mide is less likely to evoke any unwanted effect upon withdrawal. The literature only presents one case where the discontinuation of moclobemide resulted in influenza-like symptoms (Curtin, Berney, \& Kaufmann, 2002). It is, however, too early and requires more data to conclude that RIMAs are less likely to provoke withdrawal symptoms when discontinued.

\section{Use of MAO Inhibitors in the Treatment of Human Diseases}

Despite the fact that MAO inhibitors can be highly effective therapeutic agents for depression and some anxiety disorders, they tend to be underutilized in clinical practice. This is due at least in part to the fact that there is misconception and mythology about their dietary and drug interactions based on the experience with the first generation of MAO inhibitors (Grady \& Stahl, 2012).

\subsection{Depression}

For more than half a decade MAO inhibitors have been used to treat depression based on their impact on dopamine, norepinephrine and serotonin levels. In the US today, there are four MAO inhibitors approved to treat depression: isocarboxazid, phenelzine, selegiline, and tranylcypromine. Unfortunately, moclobemide although successfully used in Europe was never registered for the US market. Data from clinical studies (Stabl, Biziére, Schmid-Burgk, \& Amrein, 1989; Baumhackl et al., 1989; Versiani et al., 1989; Kok \& Tsoi, 1995; Rimón et al., 1993; Silverstone et al., 1994) suggested that moclobemide treatment was superior to placebo and comparable, as judged by an improvement of the HAM-D rating score, to imipramine, a tricyclic antidepressant, in studies treating patients suffering from major depressive disorders. The doses applied ranged from $75 \mathrm{mg} / \mathrm{d}$ to $600 \mathrm{mg} / \mathrm{d}$ and the response rates reported from $50 \%$ to $70 \%$. Moclobemide was better tolerated in all these studies than imipramine. The majority of clinical studies demonstrated that moclobemide (300 mg - $600 \mathrm{mg}$ ) was superior to placebo and thereby efficaceous in the treatment of the major depressive episodes (Bonnet, 2003). A meta-analysis of results from clinical studies comparing the effect of moclobemide with imipramine failed to reveal any difference in efficacy between moclobemide and imipramine in any subgroup of hospitalized depressives, including patients in the highest HAM-D severity band and psychotic patients (Angst, Amrein, \& Stabl, 1995). When compared to clomipramine (25 - $200 \mathrm{mg}$; tricyclic antidepressant (TCA)) moclobemide was generally better tolerated but showed mixed effects with respect to efficacy. While the majority studies show that moclobemide is equally potent to clomipramine (Guelfi et al., 1992; Jouvent et al., 1998; Kragh-Sorensen, 1993; Lecrubier \& Guelfi, 1990; Lecrubier et al., 1995), at least two studies report a better efficacy of clomipramine (Danish University Antidepressant Group, 1991; Larsen et al., 1991). Similarly, moclobemide was equally potent when compared to maprotiline (tetracyclic antidepressants (TeCA)) (Larsen et al., 1991; Gachoud, Dick, \& Köhler, 1994) and doxepine (TCA) (Steinmeyer, Vorbach, \& Arnoldt, 
1993) but with better tolerability. An additional study concluded a greater likelihood that the anticholinergic reuptake inhibitor doxep in has a higher risk of impairing sexual function than the non-anticholinergic RIMA moclobemide when comparing patients who entered the study with impaired sexual function (Lingjaerde et al., 1995).

Moclobemide was also compared to tranylcypromine in patients suffering from depression. In a randomized study on depressed patients receiving individually adjusted doses of either moclobemide (100-300 mg/day) or tranylcypromine (10 - $30 \mathrm{mg} / \mathrm{day}$ ) (Phillip, Kohnen, \& Benkert, 1993), there was no statistical difference in terms of efficacy, but the study concluded that moclobemide appeared to possess a small advantage in this regard since only one patient in this group was prematurely withdrawn from the trial due to inadequate tolerability/adverse events, compared with nine withdrawals in the tranylcypromine group. Similarly, a study in patients suffering from endogenous depression or melancholia, an atypical sub-type of MDD, showed comparable tolerance and efficacy in both groups (Rossel \& Moll, 1990). This might, however, be the case due to a low number of individuals (20 patients each) which has resulted in insufficient statistical power. In another study demonstrating an advantage for moclobemide, patients were treated concomitantly with benzodiazepines or a mild neuroleptic and an improvement on the Hamilton Rating Scale for Depression at the end of treatment of $66 \%$ for moclobemide and $41 \%$ for tranylcypromine patients was observed (Heinze et al., 1993; Gabelic \& Kuhn, 1990). While tolerance for both groups was good, the overall outcome seems to be in favour of the RIMA.

Between $33 \%$ and $47 \%$ of the depression cases fail to adequately respond to standard medication such as SSRIs (Dvir \& Smallwood, 2008). TRD is a major health concern. TRD significantly affects the patients' quality of life and adds substantially to the societal burden of this disease. An economic study by Mrazek et al. (2014), covering the period between 1996 and 2013, estimated the costs associated with TRD in the US amounted to $\$ 29-48 \$$ billion. As the combination of MAO inhibitors with other antidepressants is critical and may result in serotonin syndrome, as discussed earlier, a combination therapy should be only pursued under close supervision and care of an experienced clinician in psychiatry. A review summarizes the experience in the treatment of 29 patients suffering from TRD with MAO inhibitors and another antidepressant or stimulant medication (Thomas, Shin, McInnis, \& Bostwick, 2015). It was stated that $21 \%$ improved significantly with MAO inhibitor treatment and no complication were observed.

Two market studies by Rood Research (July 2008) and Leerink Swann (May 2012), produced a market report based on a survey of psychiatrists and primary care physicians, indicating both that a new well-balanced MAO inhibitor, RIMA, could obtain a market share of up to $30 \%$ in the US (Cennerv Pharma, unpublished data, Figure 6) in the treatment of TRD specifically if no food restrictions and washout period would apply and cross-titration during antidepressant switching would be permitted. 


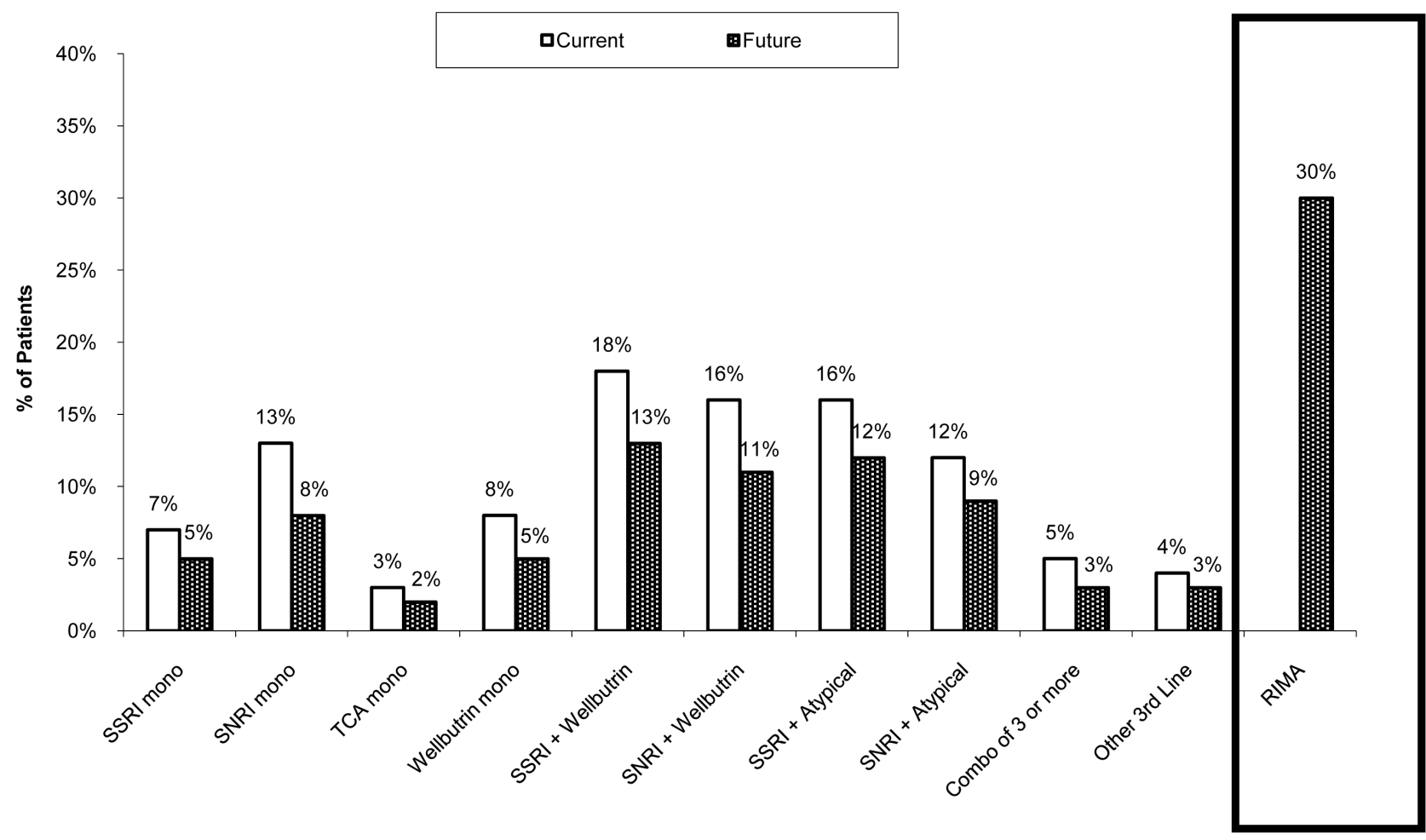

Figure 6. Current and future allocation of prescriptions for the treatment of TRD. The study performed in July 2008 by Rood Research on our behalf compared the preference of physicians to prescribe different antidepressants (SSRI = Selective serotonin reuptake inhibitors, SNRI $=$ selective norepinephrine reuptake inhibitors, TCA $=$ tricyclic antidepressants, Atypical $=$ atypical antidepressants including bupropion (Wellbutrin, Forfivo XL, Aplenzin), mirtazapine (Remeron) and nefazodone (Dutonin, Nefadar, Serzone)) for the treatment of TRD at the present time and in future.

Another therapeutic target is atypical depression. Atypical depression, despite its name, is one of the most common variants of depression, representing nearly a third of depression diagnoses. The Diagnostic and Statistical Manual of Mental Disorders in its fifth edition (American Psychiatric Association, 2013) defines atypical depression as a subtype of depression having the characteristics of reactive mood (including the ability to respond emotionally to environmental cues), increased appetite, hypersomnia, leaden paralysis, and interpersonal rejection sensitivity or when atypical features predominate during the most recent two years of dysthymic disorder (Singh \& Williams, 2006). The data in literature are limited by a small number of studies. Comparing moclobemide with fluoxetine, a SSRI, showed that moclobemide was more effective (Lonnqvist, Sihvo, Syvälahti, \& Kiviruusu, 1994). A subsequent study in the US, using the irreversible MAO inhibitor phenelzine, as moclobemide is not registered in the US, and comparing it against fluoxetine indicateded that both drugs are equally effective in the treatment of atypical depression, but phenelzine was less well tolerated (Pande et al., 1996).

In 2009, the PAROX study compared MAO inhibitors, tranylcypromine of phenelzine, with the SSRI, paroxetine, in patients with bipolar depression (Mallinger et al., 2009). While patients treated with paroxetine had an unacceptable low response rate with a durable recovery of $27 \%$, treatment with MAO inhibi- 
tors resulted in 53\% durable recovery rate. Furthermore, MAO inhibitors are less likely than other antidepressants to induce a switch to a maniac state (Zarate et al., 1995; Fiedorowicz \& Swartz, 2004).

There is a consensus, that MAO inhibitors represent an under-exploited weapon to fight depression. Evidence has been presented that patients suffering from MDD, specifically if associated with panic attacks, anxiety and agoraphobia, will benefit from MAO inhibitors (Remick, 1990; Shulman, Herrmann, \& Walker, 2013). With irreversible and non-selective MAO-inhibitors dietary precautions are required (Remick, 1990).

\subsection{Social Anxiety Disorder or Social Phobia}

Social anxiety disorder or social phobia is a disease with a lifetime prevalence rate of up to $13.3 \%$ and often onset in early adolescence (Kaspar, 1995). The main feature of social phobia is the avoidance of social interactions such as doing things in front of other people. It overlaps with social communication disorder and according to DSM-5, individuals with social communication disorder lack the ability of proper social communication while in individuals with social anxiety disorder, the social communication skills develop but are not utilized due to constant anxiety, fear, or distress about social interactions. Social phobia is distinct from other anxiety disorders and is associated with considerable incapacity (Amies, Gelder, \& Shaw, 1983; Liebowitz, Gorman, Fyer, \& Klein, 1985; Pallanti, Quercioli, \& Hollander, 2004). RIMAs have been used in clinical trials for social phobia. Brofaromine, when compared to placebo, has shown promising results with response rates between $50 \%$ and $78 \%$ and the data were consistent with the efficacy of brofaromine in the treatment of social phobia (Liebowitz, Gorman, Fyer \& Klein, 1995; Pallanti, Quercioli \& Hollander, 1997). Brofaromine, however, was not introduced to the market. Moclobemide was investigated for the treatment of social phobia in a number of studies (Versiani et al., 1992; Versiani, et al., 1997; Bisserbe \& Lépine, 1994; Noyes et al., 1997; Versiani et al., 1996; Katschnik, Murray, \& Buller, 1997; Stein, Cameron, Amrein, \& Montgomery, 1996). While the efficacy of moclobemide in treating social phobia has been controversial, most of the studies speak in favour of moclobemide being effective in the treatment of the disease. An initial study demonstrated a strong success rate at week 8 of the treatment which even improved at week 16 where $82 \%$ of the patients responded to the drug (Versiani et al., 1992). Similarly, a phase II study resulted in $45.5 \%$ being free of symptoms (Versiani et al., 1996). However, when evaluated in two multicentre trials with 506 and 578 patients in the US and Europe, South America, Canada and Australia, the results were contradictory. While in the US study (Noyes et al., 1997) the multicentre trial failed to demonstrate efficacy of moclobemide in fixed single daily doses up to $900 \mathrm{mg}$ daily in subjects with social phobia after 12 weeks, the multicentre trial in the US and Europe, South America, Canada and Australia (Katschnik, Murray, \& Buller, 1997) treating patients with $300 \mathrm{mg}$ and $600 \mathrm{mg}$ moclobemide divided over two daily doses was efficacious. A daily dose of $300 \mathrm{mg}$ showed 
better efficacy than placebo but did not reach significance. The $600 \mathrm{mg}$ daily dose was significantly effective in social phobia compared to placebo. The reason why the US study did not show the expected response was partially attributed by the authors to a high placebo effect in the study whereby week twelve approximately one third of the subjects having received placebo were judged to be much better (Noyes et al., 1997). A subsequent study in a large sample of social anxiety disorder patients with and without comorbid anxiety disorders concluded that moclobemide was both effective and well-tolerated in the short as well as longterm (Stein, Cameron, Amrein, \& Montgomery, 1996). The data confirmed and extended previous findings on the value of moclobemide in the treatment of social anxiety disorder. The authors see moclobemide as an additional therapeutic option social anxiety disorder or social phobia.

\subsection{Pain Treatment}

Although the mechanism is still unclear, antidepressants have been used since decades for the treatment of chronic pain. It is assumed that the anti-nociceptive effect is based on the increased availability of serotonin and norepinephrine in the synaptic cleft (Micó, Ardid, Berrocoso, \& Eschalier, 2006). Likewise MAO inhibitors have been explored and used in the treatment of pain since more than half a decade. The first generation of irreversible MAO inhibitors were initially used for the treatment of pain associated with angina pectoris (Cesarman, 1957; Griffith, 1960). The interest in MAO inhibitors decreased following the adverse events observed with the first class of these drugs (Blackwell \& Marley, 1964). Only when moclobemide as RIMA evolved and became available on the market, interest in the effect of MAO inhibitors in the treatment of nociceptive disorders re-emerged. An initial study in 1993 comparing different antidepressants, i.e. the tricyclic antidepressant despiramine $(75 \mathrm{mg})$, the selective serotonin reuptake inhibitor fluvoxamine $(225 \mathrm{mg}$ ) and the RIMA moclobemide, in healthy volunteers concluded that all drugs significantly increased the subjectivepain threshold (Coquoz, Porchet, \& Dayer, 1993). Only despiramine and moclobemide displayed a significant effect on the polysynaptic RIII or nociceptor flexion reflex with a maximal increase of $+25 \%$ and $+14 \%$, respectively. The data on moclobemide were confirmed in a preliminary open-label study treating patients with pain disorders suggesting that moclobemide may be a useful, effective option in the management of pain (Pirildar et al., 2003). These results were surprising as earlier data from animal studies suggested that MAO inhibition alone increased latency on a hotplate but did not increase nociceptive thresholds. The effect on nociceptive thresholds was only achieved with concomitant inhibition of serotonin uptake (Bianchi, Mantegazza, \& Panerai, 1992). As the study protocol did not include the assessment of monoamine levels, these data stand alone and cannot be interpreted conclusively.

Several studies investigated the effects of MAO inhibitors on neuropathic pain (Apaydin et al., 2001; Villarinho et al., 2013; Villarinho et al., 2012). Moclobemide was investigated in rats (Apaydin et al., 2001) and mice (Villarinho et al., 
2013) which showed an increased mechanical paw withdrawal threshold and both studies concluded that moclobemide might be a treatment alternative for symptoms of peripheral neuropathic conditions. In the mouse model, the same authors applied the MAO-B inhibitor selegiline on postoperative and neuropathic pain and concluded that MAO-B exerts a critical role in the development in these pain conditions. The data and the conclusion that allodynia or central pain sensation is mediated by $\mathrm{MAO}-\mathrm{B}$ require some caution as selegiline, in low doses, might also affect dopamine transporters and modulate levels of this neurotransmitter which has been shown to play a role in pain transmission (Lamensdorf, Porat, Simantov, \& Finberg, 1999).

The effects of moclobemide in the treatment of patients with fibromyalgia, a disorder characterized by widespread musculoskeletal pain accompanied by fatigue, sleep, memory and mood issues, was subject to two meta-analysis studies (Tort, Urrútia, Nishishinya, \& Walitt, 2012; Häuser, Bernardy, Uçeyler, \& Sommer, 2009). Both studies showed the effects of moclobemide on the symptoms of pain but did not see an effect on fatigue and sleep disturbances. For this reason, RIMAs may be evaluated as add-on treatments in fibromyalgia.

\subsection{Migraine and Tension Type Headache}

Migraines are recurrent, moderate to severe headaches. They are pulsating, often associated with vomiting, nausea, and sensitivity to light, sleep disruption, and depression and likely to affect one side of the head (Natoli et al., 2010). With the first class of MAO inhibitors, uncontrolled studies, lacking a comparison, were initiated to determine whether these drugs could be of use in the treatment of migraine and tension type headaches (Dalsgaard-Neilson, 1962; Michelacci \& Franchi, 1962). These studies were based on the hypothesis that these diseases are caused by low levels of serotonin in the brain which subsequently led to the development of triptans to act as agonists on the serotonin receptors (Kimball, Friedman \& Vallejo, 1960; Saxena \& Ferrari, 1992). Phenelzine was considered a powerful medication for migraines and daily headaches. Its use, however, was limited because of the required dietary restrictions (Sandyk \& Iacon, 1987; Robbins \& Lang, 2000). In an open clinical trial, published in 1995 (Merikangas \& Merikangas, 1995), the combination of phenelzine and the beta-blocker atenolol was assessed. The study results demonstrated that phenelzine was significantly more effective than atenolol alone in the prophylaxis of migraine but the combination was beneficial in the treatment of the psychopathology of migraine and incidences of hypertension could be reduced. When in 1991 sumatriptan became available it rapidly took a big market share (Dahlöf, 2001). In the mid-90s, moclobemide was available and was in a number of open trials investigated for its potential in the prophylaxis of migraine (Claman, 1993; Meienberg \& Amsler, 1996; Meienberg \& Amsler, 1997). The studies revealed highly promising results which should have been verified in controlled studies. Until today, however, these results have not been followed up and further studies were not published. In a 2005 study investigating the polymorphism of MAO-A and - B genes, the 
authors identified a tendency towards an association of MAO-A with migraine without aura in male subjects while there was no association of MAO-B polymorphism or MAO-B activity with migraine (Filic et al., 2005). These data suggest a re-evaluation of RIMAs for their clinical effect in the prevention of migraine episodes.

\subsection{Alzheimer's Disease (AD)}

A number of reports over the years have described elevated levels of MAO in $\mathrm{AD}$, both in blood platelets and in brain tissue (Adolfsson, Gottfries, Oreland, Wiberg, \& Winblad, 1980; Alexopoulos, Young, Lieberman, \& Shamoian, 1987; Sparks, Woeltz, \& Markesbery, 1991). Both MAO-A and MAO-B in the brain have been implicated in the etiology of Alzheimer's disease (Kennedy et al., 2003). Elevations in MAO-A in neurons of Alzheimer patients have been linked to increases in neurotoxic metabolites and neuron loss. MAO-B is elevated in plaque-associated glia in Alzheimer brain. Upregulated MAO-B enzyme levels are mainly generated through neuroinflammatory response on the formation of AD plaques (Jossan, Ekblom, Aquilonius, \& Oreland, 1994; Saura et al., 1994). As a consequence, monoamine neurotransmitter levels were found to be significantly reduced in AD patients (Gottfries et al., 1983). With age, the concentration of MAO-B in the brain increases (Oreland \& Gottfries, 1986). A number of studies in patients with $\mathrm{AD}$ have shown that up-regulated $\mathrm{MAO}$ is a reasonable biomarker for the disease (Sparks, Woeltz, \& Markesbery, 1991; Oreland \& Gottfries, 1986; Sherif, Gottfries, Alafuzoff, \& Oreland, 1992) with levels significantly up-regulated to as much as $30 \%$ (Zellner et al., 2012). Such elevated and up-regulated levels of MAO may contribute to the oxidative stress and cognitive impairment through neuroinflammation as MAO generates hydrogenperoxide and ammonia which are among the main culprits contributing to the formation of amyloid plaques (Huang et al., 2012; Zheng, Fridkin, \& Youdim, 2012).

It is thus not surprising that a number of trials have been initiated to investigate the potential of MAO inhibitors for the treatment of $\mathrm{AD}$. Currently, a 24week placebo-controlled, proof-of-concept study [NCT02359552] is on its way to evaluate the effect of rasagiline, a registered MAO-B inhibitor used for the treatment of Parkinson's disease, in regional brain metabolism in patients with mild to moderate Alzheimer's disease. Researchers will assess whether taking rasagiline improves brain metabolism in people with Alzheimer's disease, as measured by a brain scan using ${ }^{18} \mathrm{~F}$-2-fluoro-2-deoxy-D-glucose (FDG-PET). This study is expected to deliver results by December 2016. In June 2015, Roche (Switzerland) reported the failure of sembragiline to meet the primary endpoint in a Phase IIB AD study (Evotec, press release, 30 June 2015) https://www.evotec.com/uploads/cms_article/2739/PR_2015-06-30_Roche_e.pdf. On the research side, attempts are on the way to evaluate molecules which combine the activity to inhibit monoamine oxidase with the inhibition of cholinesterase, a proven target for the management of $\mathrm{AD}$ symptoms (Bolea et al., 2011; Yáñez \& Viña, 2013; Bautista-Aguilera et al., 2014; Wu et al., 2016). Earlier 
attempts to prevent aggregation and the disposition of $\mathrm{AD}$ plaques through the administration of metal ion chelators (Cuajungco et al., 2000) have found new interest through the combination with monoamine oxidase inhibition ( $\mathrm{Li}$ et al., 2016; Avramovich-Tirosh et al., 2007). The validity of these approaches, however, will require the generation of supportive data from controlled studies in $\mathrm{AD}$ patients.

\subsection{Parkinson's Disease (PD)}

$\mathrm{PD}$ is a progressive disorder of the nervous system that is characterized by a deficiency of the neurotransmitter dopamine and degeneration of presynaptic dopaminergic terminals (Bravi et al., 1994). The disease manifests by tremor, muscular rigidity, and slow, imprecise movement, changes in speech and gait and mainly affects middle-aged and elderly people. The main current therapy is levodopa. Patients, however, experience a progressive shortening of its antiparkinsonian action (wearing-off) as a function of presynaptic degeneration (Bravi et al., 1994). As MAO is responsible inter-alia for the degradation of dopamine and both subtypes of MAO recognize dopamine as substrate, MAO inhibitors have been investigated as an approach to lessening the wearing-off phenomena (Sternic et al., 1998; Shapira, 2011). There is reasoning for both, MAO-A and MAO-B inhibitors, in the treatment of PD. On the one hand, dopamine is metabolized to a much lesser degree by MAO-A (23\%) than MAO-B (77\%) (Oreland, 1991), on the other hand MAO-A, due to its location in the extra-and intra-neuronal space, significantly contributes to the metabolism of dopamine while MAO-B is mainly located extra-neuronally in primates. It has therefore been speculated (Sternic et al., 1998) that MAO-A inhibitors or both, MAO-A and MAO-B inhibitors, would be more effective in treating the motor complications associated with long-term levo-dopa treatment. Interestingly, initial attempts to evaluate moclobemide in PD resulted in a significant reduction of the "off" periods (refers to period when the medicine does not work during the day and symptoms are worsened) without affecting the symptoms during the "on" periods or changing the unified Parkinson's disease rating scale (UPDRS) (Sternic et al., 1998; Ruggieri et al., 1994; Ruggieri et al., 1996). On the other hand, the MAO-B inhibitors selegiline and rasagiline have been widely reported to alleviate the symptoms of PD (Ahlskog et al., 1996; Parkinson Study Group, 1993, 2004; Shoulson, 1998; Rascol et al., 2005). In 2009, the FDA expanded the indication for rasagiline from monotherapy and adjunct to levodopa to include adjunct to dopamine agonists. A recent cross-sectional cohort study reviewed the outcome of clinical MAO-B inhibitor investigation and demonstrated that MAO-B inhibitor therapy was associated with reduced risk of dyskinesia in patients with PD (Dashtipour et al., 2015). Currently, safinamide, approved in the $\mathrm{EU}$, is waiting for regulatory approval as an add-on therapy to stable-dose levodopa, alone or in combination with other PD therapies in mid- to late-stage fluctuating PD patients (Deeks, 2015).

As the reaction products of MAO increase the oxidative stress and might be 
cytotoxic to neurons in the substantia nigra compacta of PD patients, it was reasoned that the inhibition of MAO might prevent neurodegeneration and provide neuroprotection. Both $\mathrm{MAO}-\mathrm{A}$ and $\mathrm{MAO}-\mathrm{B}$ are being discussed to provide beneficial, neuroprotective effects for PD patients (Naoi, Maruyama, Inaba-Hasegawa, \& Akao, 2011; Robakis \& Fahn, 2015; Kong et al., 2015). It has been demonstrated that MAO-A mediates the increased expression of genes for antiapoptotic, pro-survival $\mathrm{Bcl}-2$, a subgroup of the $\mathrm{Bcl}-2$ family of proteins regulating apoptosis, whereas MAO-B does not. The authors speculate that MAO-A inhibitors can induce pro-survival genes and that MAO-A is expected to play a role in disease-modifying therapy for neurodegenerative disorders (Naoi, Maruyama, \& Inaba-Hasegawa, 2012).

\subsection{Smoking}

Both MAO-A and MAO-B levels have been implicated to play a role in smoking cessation (Fowler, Logan, Wang, \& Volkow, 2003) and a number of early studies have reported that smokers have reduced MAO levels as compared to nonsmokers (Fowler et al., 1996; Oreland, Fowler \& Schalling, 1981; Norman, Chamberlain, \& French, 1987; Norman, Chamberlain, French, \& Burrows, 1982; Von Knorring \& Oreland, 1985). Initially, low levels of MAO were considered to be a predisposing factor for the development of neurological diseases such as MDD and schizophrenia (Buchsbaum, Coursey, \& Murphy, 1976; Wyatt et al., 1980). Subsequent studies, however, clearly demonstrated that reduced MAO activity was rather caused by smoking per se rather than being a type of biomarker or predisposition for the disease (Berlin, Spreux-Varoquaux, Saï, \& Launay, 1997; Simpson et al., 1999). In-vitro studies confirmed that harman and norhaman alkaloids found in tobacco smoke inhibit MAO-A and both MAO-A/MAOB, respectively (Herraiz \& Chaparro, 2005).

The correlation of smoking and depression initiated clinical trials to show cigarette smoking as potential self-medication to treat depression symptoms. In one such trial moclobemide was used to facilitate smoking cessation in heavy smokers (Berlin et al., 1995). It was confirmed that the abstinence rate was higher with moclobemide (400 mg/day) than with placebo $(\mathrm{n}=44)$. Even though the data of the study were considered promising, the authors stated that data from a larger cohort would be required to make a definitive conclusion. Unfortunately, no further results for the activation of moclobemide to facilitate smoking cessation have since been published. The interest in the use of MAO-A inhibitors for this indication is exemplified by a recent publication of in-vitro data describing a class of novel benzoxathiolone MAO-A inhibitors to be profiled in this indication (Mostert, Petzer, \& Petzer, 2016).

Likewise, MAO-B inhibitors were investigated for their potential as smoking cessation agents. At Yale University selegiline (5 mg bid) was compared to placebo during a 8 week controlled trial of nicotine-dependent smokers $(n=40)$ and the results showed a $45 \%$ cessation rate in the seligeline group as compared to $15 \%$ in the placebo group (George et al., 2003). These data were not repro- 
duced when investigated in a larger patient cohort where no improvement over placebo was observed (Weinberger et al., 2010). Similarly, a study with 108 participants in Israel also failed to demonstrate superiority over placebo (Biberman, Neumann, Katzir, \& Gerber, 2003). A transdermal patch of selegiline in combination with cognitive behaviour training treating 243 adult smokers also did not show a statistical difference to placebo (Killen et al., 2010). A few years ago, Berlin and colleagues investigated a selective reversible MAO-B inhibitor for its effect on smoking cessation (Berlin et al., 2012). In this randomized double blind, placebo-controlled phase II trial, sembragiline was compared to placebo. The authors concluded that the selective, reversible MAO-B inhibitor sembragiline was not superior to placebo in helping smokers quit confirming that MAO-B inhibitors are not effective in smoking cessation.

\subsection{Other Diseases}

Reasearch is going on to identify other diseases where MAO inhibitors could provide beneficial differences, either as co-medication or in stand-alone therapies. Representative examples are diabetic cardiomyopathy and prostate cancer. Umbarkar et al. (2015) treated streptozotocin-induced diabetic rats for a period of 8 days with the MAO-A-specific, irreversible inhibitor, clorgiline. Diabetes in those animals increased a number of stress markers and induced fibrosis. Treatment with the MAO-A inhibitor improved all these parameters despite persistent hyperlipidemia and hyperglycemia. The authors speculated that these improvements were the results of a reduction of oxidative stress induced by the MAO-A inhibitor.

Not much was known on the importance of MAOs in cancer until in 2006 when a genetic study confirmed that MAO-A was one of the most highly differentially expressed genes at the transcript level in prostate cancer. The authors identified a correlation between MAO-A inhibition and the severity of the disease according to the Gleason grading system for prostate adenocarcinoma (True et al., 2006). In-vitro experiments demonstrated that treatment of high grade prostatic cancer cells ( $\mathrm{VCaP}$ ) derived in 2001 from a patient with androgen-independent prostate cancer ( $\mathrm{PCa}$ ) with the MAO-A-selective inhibitor clorgyline slowed the tumor growth and induced transcriptome changes on genes involved in oncogenesis and differentiation (Korenchuk et al., 2001; Zhao, Flamand, \& Peehl, 2009). The authors concluded that MAO-A expression in high-grade PCa might have a direct role in maintaining the de-differentiated phenotype and increases aggressive behaviour of the cancer cells. Subsequent experiments in mice bearing $\mathrm{VCaP}$ xenografts conducted by the Stamford group confirmed the in-vitro experiments when animals were treated with clorgyline. The data on the inhibition of tumor growth in a PCA xenograft model were confirmed by a research consortium from the US and China (Wu et al., 2014) showing that MAO-A knockdown in a mouse xenograft model significantly reduced tumor growth but also disengaged the downstream signalling model of MAO-A driving hypoxia, oxidative stress and epithelial, mesenchymal transition 
[EMT], an important step whereby tumor cells acquire a more invasive and metastatic phenotype (Thiery, 2002). Additionally, the research team in the US generated a near-infrared labelled inhibitor of MAO-A based on the structure of clorgyline to study it in mouse PCa xenografts. They demonstrated reduced expression of oncogenes Fos, Jun, NF-kB, and Myc and cell cycle regulators CCND1, CCNE1, and CDK4/6, along with increases in the levels of tumor suppressor gene TP53, cell cycle inhibitors CDKN1A and CDKN2A, and MAOA-downstream genes that promote EMT, tumor hypoxia, cancer cell migration, and invasion (Wu et al., 2014, 2015). These data warrant further investigation of RIMAs in the treatment of prostate cancer.

A Korean research team recently published that the MAO inhibitors pargyline and tranylcypromine affected the cell cycle in human prostate carcinoma (LNCAP-LN3) cells and that pargyline was more effective than tranylcypromine (Lee et al., 2013). Efficacy of pargyline to inhibit the growth of breast cancer cells has also been described (Lee et al., 2012). At this point it is not clear whether MAO-B inhibitors have significant effects in tumor growth inhibition or whether the effect as described for pargyline has been evoked by interacting with MAO-A and MAO-B concomitantly. Pargyline has been described to have only slight selectivity for MAO-B (Fuller \& Hemrick, 1978). In contrast to MAO-A, MAO-B is expressed in normal prostate tissue and its levels are substantially reduced in PCa tissue (Xu et al., 2015).

\section{Conclusion}

MAO enzymes inhibitors have now been used in therapy for more than half a century. The initial attempts to use this class of drugs were doomed by their side effects (i.e. hypertensive crisis and liver toxicity) linked to their irreversible mechanism of action. Scientific interest in MAOs has not decreased and several hundred research papers are being published every year (Figure 7). Concomitantly, novel and selective MAO inhibitors were identified with selectivity and

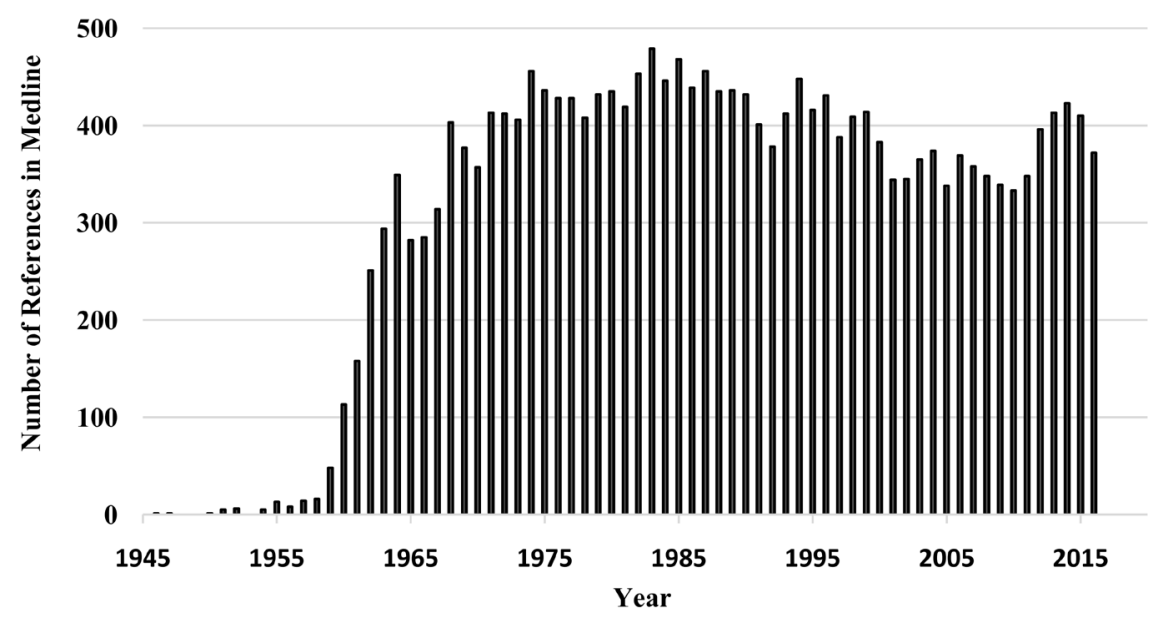

Figure 7. Research papers published on MAOs and their inhibitors for the last decades (Source: Pubmed http://www.ncbi.nlm.nih.gov/pubmed, search term: monoamine oxidase, last visited 19 December 2016). 
better tolerability. These agents, and here specifically the RIMAs, provide physicians with another treatment alternative for patients who failed to respond to other treatment options (Targum et al., 2014). They also can be explored to evaluate the effectiveness of MAO-A inhibitors in other, new indications.

\section{References}

Adolfsson, R., Gottfries, C. G., Oreland, L., Wiberg, A., \& Winblad, B. (1980). Increased Activity of Brain and Platelet Monoamine Oxidase in Dementia of Alzheimer Type. Life Sciences, 27, 1029-1034. https://doi.org/10.1016/0024-3205(80)90025-9

Ahlskog, J. E., Uitti, R.J., Low, P. A., Tyce, G. M., O’Brien, J. F., \& Nickander, K. K. (1996). Levodopa and Deprenyl Treatment Effects on Peripheral Indices of Oxidant Stress in Parkinson's Disease. Neurology, 46, 796-801. https://doi.org/10.1212/WNL.46.3.796

Alexopoulos, G. S., Young, R. C., Lieberman, K. W., \& Shamoian, C. A. (1987). Platelet MAO Activity in Geriatric Patients with Depression and Dementia. American Journal of Psychiatry, 144, 1480-1483. https://doi.org/10.1176/ajp.144.11.1480

Ama, O. B., Amita, T., \& Youdim, M. B. H. (2004). Contrasting Neuroprotective and Neurotoxic Actions of Respective Metabolites of Anti-Parkinson Drugs Rasagiline and Selegiline. Neuroscience Letters, 355, 169-172. https://doi.org/10.1016/j.neulet.2003.10.067

American Psychiatric Association (2013). Diagnostic and Statistical Manual of Mental Disorders, Fifth Edition (DSM-5). American Psychiatric Association.

Amies, P. L., Gelder, M. G., \& Shaw, P. M. (1983). Social Phobia: A Comparative Clinical Study. British Journal of Psychiatry, 142, 174-179. https://doi.org/10.1192/bjp.142.2.174

Anderson, M. C., Hasan, F., McCrodden, J. M., \& Tipton, K. F. (1993). Monoamine Oxidase Inhibitors and the Cheese Effect. Neurochemical Research, 8, 1145-1149. https://doi.org/10.1007/BF00978365

Angst, J, Amrein, R., \& Stabl, M. (1995). Moclobemide and Tricyclic Antidepressants in Severe Depression: Meta-Analysis and Prospective Studies. Journal of Clinical Psychopharmacology, 15, 16S-23S. https://doi.org/10.1097/00004714-199508001-00004

Apaydin, S., Goldeli, E., Uyar, M., Erhan, E., Yegul, I., \& Tuglular, I. (2001). The Antinociceptive Effect of Moclobemide on the Vocalization Threshold to Paw Pressure in a Rat Model of Unilateral Mononeuropathy. Pharmacological Research, 44, 503-507. https://doi.org/10.1006/phrs.2001.0895

Atchley, D. W. (1964). Reevaluation of Tranylcypromine Sulfate (Parnate Sulfate). Journal of the American Medical Association, 189, 763-764. https://doi.org/10.1001/jama.1964.03070100057011

Avramovich-Tirosh, Y., Amit, T., Bar-Am, O., Zheng, H., Fridkin, M., \& Youdim, M. B. (2007). Therapeutic Targets and Potential of the Novel Brain-Permeable Multifunctional Iron Chelator-Monoamine Oxidase Inhibitor Drug, M-30, for the Treatment of Alzheimer's Disease. Journal of Neurochemistry, 100, 490-502. https://doi.org/10.1111/j.1471-4159.2006.04258.x

Baker, G. B., Urichuk, L. J., McKenna, K. F., \& Kennedy, S. H. (1999). Metabolism of Monoamine Oxidase Inhibitors. Cellular and Mololecular Neurobiology, 19, 411-426. https://doi.org/10.1023/A:1006982732681

Baumhackl, U., Bizière, K., Fischbach, R., Geretsegger, C., Hebenstreit, G., Radmayr, E., \& Stabl, M. (1989). Efficacy and Tolerability of Moclobemide Compared with Imipramine in Depressive Disorder (DSM-III): An Austrian Double-Blind, Multicentre Study. British Journal Psychiatry, 6, 78-83. 
Bautista-Aguilera, O. M., Esteban, G., Chioua, M., Nikolic, K., Agbaba, D., Moraleda, I., Iriepa, I., Soriano, E., Samadi, A., Unzeta, M., \& Marco-Contelles, J. (2014). Multipotent Cholinesterase/Monoamine Oxidase Inhibitors for the Treatment of Alzheimer's Disease: Design, Synthesis, Biochemical Evaluation, ADMET, Molecular Modeling, and QSAR Analysis of Novel Donepezil-Pyridyl Hybrids. Drug, Design, Development and Therapy, 8, 1893-1910.

Befol-4DOKTOR. RU Drug Information Handbook. http://www.4doktor.ru/default.aspx?drugid=35741.

Bellon, A., \& Coverdale, J. H. (2009). Delirium, Thrombocytopenia, Insomnia, and Mild Liver Damage Associated with MAOI Withdrawal. European Journal of Clinical Pharmacology, 65, 1269-1270. https://doi.org/10.1007/s00228-009-0711-y

Berlin, I., Hunneyball, I. M., Greiling, D., Jones, S. P., Fuder, H., \& Stahl, H. D. (2012). A Selective Reversible Monoamine Oxidase B Inhibitor in Smoking Cessation: Effects on Its Own and in Association with Transdermal Nicotine patch. Psychopharmacology (Berlin), 223, 89-98. https://doi.org/10.1007/s00213-012-2692-2

Berlin, I., Saïd, S., Spreux-Varoquaux, O., Launay, J. M., Olivares, R., Millet, V., Lecrubier, Y., \& Puech, A. J. (1995). A Reversible Monoamine Oxidase A Inhibitor (Moclobemide) Facilitates Smoking Cessation and Abstinence in Heavy, Dependent Smokers. Clinical Pharmacology \& Therapeutics, 58, 444-452.

https://doi.org/10.1016/0009-9236(95)90058-6

Berlin, I., Spreux-Varoquaux, O., Saïd, S., \& Launay, J. M. (1997). Effects of Past History of Major Depression on Smoking Characteristics, Monoamine Oxidase-A and -B Activities and Withdrawal Symptoms in Dependent Smokers. Drug and Alcohol Dependence, 45, 31-37. https://doi.org/10.1016/S0376-8716(97)01338-0

Bianchi, M., Mantegazza, P., \& Panerai, A. E. (1992). Effects of Two Different Reversible Monoamine Oxidase-A Inhibitors on Nociceptive Thresholds in the Rat. European Journal of Pharmacology, 219, 113-116. https://doi.org/10.1016/0014-2999(92)90587-T

Biberman, R., Neumann, R., Katzir, I., \& Gerber, Y. (2003). A Randomized Controlled Trial of Oral Selegiline plus Nicotine Skin Patch Compared with Placebo plus Nicotine Skin Patch for Smoking Cessation. Addiction, 98, 1403-1407. https://doi.org/10.1046/j.1360-0443.2003.00524.x

Bisserbe, J. C., \& Lépine, J. P. (1994). Moclobemide in Social Phobia: A Pilot Open Study. Clinical Neuropharmacology, 17, S88-S94. https://doi.org/10.1097/00002826-199417001-00010

Black, K. J., Hershey. T., Koller, J. M., Videen, T. O., Mintun, M. A., Price, J. L., \& Perlmutter, J. S. (2002). A Possible Substrate for Dopamine-Related Changes in Mood and Behavior: Prefrontal and Limbic Effects of a D3-Preferring Dopamine Agonist. Proceedings of the National Academy of Sciences of the United States of America, 99, 17113-17118. https://doi.org/10.1073/pnas.012260599

Blackwell, B., \& Marl, E. (1964). Interaction between Cheese and Monoamine Oxidase Inhibitors in Rats and Cats. The Lancet, 1, 530-531. https://doi.org/10.1016/S0140-6736(64)92914-9

Blackwell, B., \& Marley, E. (1966) Interactions of Cheese and of Its Constituents with Monoamine Oxidase Inhibitors. British Journal of Pharmacology and Chemotherapy, 26, 120-141. https://doi.org/10.1111/j.1476-5381.1966.tb01816.x

Blackwell, B. (1963). Tranylcypromine. The Lancet, 282, 414. https://doi.org/10.1016/S0140-6736(63)93105-2

Blows, W. T. (2000). Neurotransmitters of the Brain: Serotonin, Noradrenaline (Norepinephrine), and Dopamine. Journal of Neuroscience Nursing, 32, 234-238. https://doi.org/10.1097/01376517-200008000-00008 
Bolea, I., Juárez-Jiménez, J., de Los Ríos, C., Chioua, M., Pouplana, R., Luque, F. J., Unzeta, M., Marco-Contelles, J., \& Samadi, A. (2011). Synthesis, Biological Evaluation, and Molecular Modeling of Donepezil and N-[(5-(benzyloxy)-1-methyl-1H-indol-2yl)methyl]-N-methylprop-2-yn-1-amine Hybrids as New Multipotent Cholinesterase/ Monoamine Oxidase Inhibitors for the Treatment of Alzheimer's Disease. Journal of Medicinal Chemistry, 54, 8251-8270. https://doi.org/10.1021/jm200853t

Bonnet, U. (2003). Moclobemide: Therapeutic Use and Clinical Studies. CNS Drug Reviews, 9, 97-140. https://doi.org/10.1111/j.1527-3458.2003.tb00245.x

Bravi, D., Mouradian, M. M., Roberts, J. W., Davis, T. L., Sohn, Y. H., \& Chase, T.N. (1994). Wearing-Off Fluctuations in Parkinson's Disease: Contribution of Postsynaptic Mechanisms. Annals of Neurology, 36, 27-31. https://doi.org/10.1002/ana.410360108

Bryant, J. M., Torosdag, S., Schvartz, N., Fletcher, L. Jr., Fertig, H., Schwartz, M. S., \& Quan, R. B. (1961). Antihypertensive Properties of Pargyline Hydrochloride. New Non-Hydrazine Monoamine Oxidase Inhibitor Compared with Sulphonamide Diuretics. Journal of the American Medical Association, 178, 406-409.

Buchsbaum, M. S., Coursey, R. D., \& Murphy, D. L. (1976) The Biochemical High-Risk Paradigm: Behavioral and Familial Correlates of Low Platelet Monoamine Oxidase Activity. Science, 194, 339-341. https://doi.org/10.1126/science.968488

Burch, D., Asgharnejad, M., Gerson, W., Fielding, R. M., \& Azzaro, A.J. (2014). Lack of Tyramine Pressor Response Effect with Oral CX157: A Specific Reversible MAOI. Clinical Pharmacology in Drug Devopment, 3, 4-12. https://doi.org/10.1002/cpdd.61

Castilla del Pino, C. (1955). Síndrome hiperesténico. Alteraciones de la personalidad consecutivas a la terapéutica hidrazídica. Actas Luso-Espanolas De Neurologia $Y$ Psiquiatria, 14, 210-219.

Cesarman, T. (1957). Serendipitia y angina de pecho. Informe preliminar sobre hallazgo therapeutico. Archivos del Instituto de Cardiologia de Mexico, 27, 563-580.

Checchini, S., Petri, P., Ardito, R., Bareggi, S. R., \& Torriti, A. (1978). A Comparative Double-Blind Trial of the New Antidepressant Caroxazone and Amitriptyline. Journal of International Medical Research, 6, 388-394. https://doi.org/10.1177/030006057800600507

Chen, D. T., \& Ruch, R. (1993). Safety of Moclobemide in Clinical Use. Clinical Neuropharmacology, 16, S63-S68.

Chessin, M., Dubnick, B., Kramer, E. R., \& Scott, C. C. (1957). Modifications of Pharmacology of Reserpine and Isoproniazid. Journal of Pharmacology and Experimental Therapeutics, 119, 453-460.

Claman, J. M. (1993). The Potential Effectiveness of Moclobemide, the New Monoamine Oxidase Inhibitor, in the Prophylaxis of Migraine. Headache, 33, 339. https://doi.org/10.1111/j.1526-4610.1993.hed3306339.x

Coquoz, D., Porchet, H. C., \& Dayer P. (1993). Central Analgesic Effects of Desipramine, Fluvoxamine, and Moclobemide after Single Oral Dosing: A Study in Healthy Volunteers. Clinical Pharmacology \& Thereutics, 54, 339-344. https://doi.org/10.1038/clpt.1993.156

Cuajungco, M. P., Fagét, K. Y., Huang, X., Tanzi, R. E., \& Bush, A. I. (2000). Metal Chelation as a Potential Therapy for Alzheimer's Disease. Annals of the New York Academy of Sciences, 920, 292-304. https://doi.org/10.1111/j.1749-6632.2000.tb06938.x

Curet, O., Damoiseau, G., Aubin, N., Sontag, N., Rovei, V., \& Jarreau, F.-X. (1996). Befloxatone, a New Reversible and Selective Monoamine Oxidase-A Inhibitor. I. Biochemical Profile. Journal of Pharmacology and Experimental Therapeutics, 277, 253 264.

Curtin, F., Berney, P., \& Kaufmann, C. (2002). Moclobemide Discontinuation Syndrome 
Predominantly Presenting with Influenza-Like Symptoms. Journal of Psychopharmacology, 16, 271-272. https://doi.org/10.1177/026988110201600314

Da Prada, M., Kettler, R., Keller, H. H., Burkard, W. P., Muggli-Maniglio, D., \& Haefely, W.E. (1989). Neurochemical Profile of Moclobemide, a Short-Acting and Reversible Inhibitor of Monoamine Oxidase Type A. Journal of Pharmacology and Experimental Therapeutics, 248, 400-414.

Dahlöf, C. G. H. (2001). Sumatriptan: Pharmacological Basis and Clinical Results. Current Medical Research Opinion, 17, s35-s45. https://doi.org/10.1185/0300799039117010

Dalsgaard-Neilson, A. T. (1962). Behandling of Migraine-Patienter med Niamid. Ugeskrift for Læger, 124, 10-11.

Danish University Antidepressant Group (1991). Moclobemide: A Reversible MAO-AInhibitor Showing Weaker Antidepressant Effect Than Clomipramine in a Controlled Multicenter Study. Journal of Affective Disorders, 28, 105-116.

Dashtipour, K., Chen, J. J., Kani, C., Bahjri, K., \& Ghamsary, M. (2015). Clinical Outcomes in Patients with Parkinson's Disease Treated with a Monoamine Oxidase Type-B inhibitor: A Cross-Sectional, Cohort Study. Pharmacotherapy, 35, 681-686. https://doi.org/10.1002/phar.1611

Deeks, E. D. (2015). Safinamide: First Global Approval. Drugs, 75, 705-711. https://doi.org/10.1007/s40265-015-0389-7

Delumeau, J. C., Bentué-Ferrer, D., Gandon, J. M., Amrein, R., Belliard, S., \& Allain, H. (1994). Monoamine Oxidase Inhibitors, Cognitive Functions and Neurodegenerative Diseases. Journal of Neurotransmission Supplement, 41, 259-266.

Dilsaver, S. C. (1988). Monoamine Oxidase Inhibitor Withdrawal Phenomena: Symptoms and Pathophysiology. Acta Psychiatrica Scandinavica, 78, 1-7. https://doi.org/10.1111/j.1600-0447.1988.tb06293.x

Dorrell, W. (1963). Tranylcypromine and Intracranial Bleeding. The Lancet, 282, 414. https://doi.org/10.1016/S0140-6736(63)93106-4

Dvir, Y., \& Smallwood, P. (2008). Serotonin Syndrome: A Complex but Easily Avoidable Condition. General Hospital Psychiatry, 30, 284-287. https://doi.org/10.1016/j.genhosppsych.2007.09.007

Emilien, G. (1999). Befloxatone (Synthelabo). IDrugs, 2, 247-253.

Esuprone. AdisInsights. http://adisinsight.springer.com/drugs/800005281

Evotec, Press Release, 30 June 2015. https://www.evotec.com/uploads/cms_article/2739/PR_2015-06-30_Roche_e.pdf

Feighner, J. P., Herbstein, J., \& Damlouji, N. (1985). Combined MAOI, TCA and Direct Stimulant Therapy of Treatment-Resistant Depression. Journal of Clinical Psychiatry, 46, 206-209.

Fernandez, H. H., \& Chen, J. J. (2007) Monoamine Oxidase-B Inhibition in the Treatment of Parkinson's Disease. Pharmacotherapy, 27, 174S-185S.

https://doi.org/10.1592/phco.27.12part2.174S

Fiedorowicz, J. G., \& Swartz, K. L. (2004). The Role of Monoamine Oxidase Inhibitors in Current Psychiatric Practice. Journal of Psychiatric Practice, 10, 239-248. https://doi.org/10.1097/00131746-200407000-00005

Filic, V., Vladic, A., Stefulj, J., Cicin-Sain, L., Balija, M., Sucic, Z., \& Jernej, B. (2005). Monoamine Oxidases A and B Gene Polymorphisms in Migraine Patients. Journal of the Neurological Sciences, 228, 149-153. https://doi.org/10.1016/j.jns.2004.11.045

Finberg, J. P., Lamensdorf, I, Commissiong, J. W., \& Youdim, M. B. (1996). Pharmacology and Neuroprotective Properties of Rasagiline. Journal of Neural Transmission, 48, 95-101. 
Folks, D. G. (1983). Monoamine Oxidase Inhibitors: Reappraisal of Dietary Considerations. Journal of Clinical Psychopharmacology, 3, 249-252. https://doi.org/10.1097/00004714-198308000-00011

Fowler, J. S., Logan, J., Azzaro, A. J., Fielding, R. M., Wei, Z. W., Poshusta, A. K., Burch, D., Brand, B., Free, J., Asgharnejad, M., Wang, G. J., Telang, F., Hubbard, B., Jayne, M., King, P., Carter, P., Carter, S., Xu, Y., Shea, C., Muench, L., Alexoff, D., Shumay, E., Schueller, M., Warner, D., \& Apelskog-Torres, K. (2010). Reversible Inhibitors of Monoamine Oxidase-A (RIMAs): Robust, Reversible Inhibition of Human Brain MAO-A by CX157. Neuropsychopharmacology, 35, 623-631.

https://doi.org/10.1038/npp.2009.167

Fowler, J. S., Logan, J., Wang, J., \& Volkow, N. D. (2003). Monoamine Oxidase and Cigarette Smoking. Neurotoxicology, 24, 75-82. https://doi.org/10.1016/S0161-813X(02)00109-2

Fowler, J. S., Volkow, N. D., Wang, G. J., Pappas, N., Logan, J., MacGregor, R., Alexoff, D., Shea, C., Schlyer, D., Wolf, A. P., Warner, D., Zezulkova, I., \& Cilento, R. (1996). Inhibition of Monoamine Oxidase B in the Brains of Smokers. Nature, 379, 733-736. https://doi.org/10.1038/379733a0

Fuller, R. W., \& Hemrick, S. K. (1978). Enhanced Selectivity of Pargyline as an Inhibitor of Type B Monoamine Oxidase in Harmaline-Treated Rats. Life Sciences, 22, $1083-$ 1086. https://doi.org/10.1016/0024-3205(78)90278-3

Fung, M., Thornton, A., Mybeck, K., Wu, J. H., Hornbuckle, K., \& Muniz, E. (2001). Evaluation of the Characteristics of Safety Withdrawal of Prescription Drugs from Worldwide Pharmaceutical Markets-1960 to 1999. Therapeutic Innovation \& Regulatory Science, 35, 293-317. https://doi.org/10.1177/009286150103500134

Furst, W. (1959). Therapeutic Re-Orientation in Some Depressive States: Clinical Evaluation of a New Mono-Amine Oxidase Inhibitor (W-1554-A, Phenelzine, Nardil). American Journal of Psychiatry, 116, 429-434. https://doi.org/10.1176/ajp.116.5.429

Gabelic, I., \& Kuhn, B. (1990). Moclobemide (Ro 11-1163) versus Tranylcypromine in the Treatment of Endogenous Depression. Acta Psychiatrica Scandinavica, 360, 63. https://doi.org/10.1111/j.1600-0447.1990.tb05334.x

Gachoud, J.-P., Dick, P., \& Köhler, M. (1994). Comparison of the Efficacy and Tolerability of Moclobemide and Maprotiline in Depressed Patients Treated by General Practioners. Clinical Neuropharmacology, 17, S29-S37. https://doi.org/10.1097/00002826-199417001-00005

George, T. P., Vessicchio, J. C., Termine, A., Jatlow, P. I., Kosten, T. R., \& O’Malley, S. S. (2003). A Preliminary Placebo-Controlled Trial of Selegiline Hydrochloride for Smoking Cessation. Biological Psychiatry, 53, 136-143. https://doi.org/10.1016/S0006-3223(02)01454-3

Gillman, P. K. (2007). Tricyclic Antidepressant Pharmacology and Therapeutic Drug Interactions Updated. British Journal of Pharmacology, 151, 737-748. https://doi.org/10.1038/sj.bjp.0707253

Giroud, C., Horisberger, B., Eap, C., Augsburger, M., Ménétrey, A., Baumann, P., \& Mangin, P. (2004) Death Following Acute Poisoning by Moclobemide. Forensic Science International, 140, 101-107. https://doi.org/10.1016/j.forsciint.2003.10.021

Gottfries, C. G., Adolfsson, R., Aquilonius, S. M., Carlsson, A., Eckernäs, S. A., Nordberg, A., Oreland, L., Svennerholm, L., Wiberg, A., \& Winblad, B. (1983). Biochemical Changes in Dementia Disorders of Alzheimer Type (AD/SDAT). Neurobiology of Ag ing, 4, 261-271. https://doi.org/10.1016/0197-4580(83)90002-7

Grady, M. M., \& Stahl, S.M. (2012). Practical Guide for Prescribing MAOIs: Debunking Myths and Removing Barriers. CNS Spectrum, 17, 2-10. 
https://doi.org/10.1017/S109285291200003X

Griffith, G. C. (1960). Amine Oxidase Inhibitors; Their Current Place in the Therapy of Cardiovascular Diseases. Circulation, 22, 1156-1165.

https://doi.org/10.1161/01.CIR.22.6.1156

Guelfi, J. D., Payan, C., Fermanian, J., Pedarriosse, A. M., \& Manfredi, R. (1992). Moclobemide vs. Clomipramine in Endogenous Depression. A Double-Blind Randomized Clinical Trial. British Journal of Psychiatry, 160, 519-524. https://doi.org/10.1192/bjp.160.4.519

Haefely, W., Burkard, W. P, Cesura, A. M., Kettler, R., Lorez, H. P., Martin, J. R., Richards, J. G., Scherschlicht, R., \& De Prada, M. (1992). Biochemistry and Pharmacology of Moclobemide, a Prototype RIMA. Psychopharmacology, 196, S6-S14.

https://doi.org/10.1007/BF02246225

Häuser, W., Bernardy, K., Uçeyler, N., \& Sommer, C. (2009). Treatment of Fibromyalgia Syndrome with Antidepressants: A Meta-Analysis. Journal of the American Medical Association, 301, 198-209. https://doi.org/10.1001/jama.2008.944

Heinrich, K., \& Petrilowitch, N. (1960). [On the Psychopathology and Clinical Aspects of Hydrazines. Comparative Studies with Nialamide, Serine-Isopropylhydrazide and Isocarboxazide]. Medicina Espanol, 2, 162-170.

Heinze, G., Rossel, L., Gabelic, I., Galeano-Munoz, J., Stabl, M., \& Allen, S. R. (1993). Double-Blind Comparison of Moclobemide and Tranylcypromine in Depression. Pharmacopsychiatry, 26, 240-245. https://doi.org/10.1055/s-2007-1014361

Henchcliffe, C., Schumacher, H. C., \& Burgut, F. T. (2005). Recent Advances in Parkinson's Disease Therapy: Use of Monoamine Oxidase Inhibitors. Expert Review in Neurotherapy, 5, 811-821. https://doi.org/10.1586/14737175.5.6.811

Hernandez, A. F., Montero, M. N, Pla, A., \& Villanueva, E. (1995). Fatal Moclobemide Overdose or Death Caused by Serotonin Syndrome? Journal of Forensic Sciences, 40, 128-130. https://doi.org/10.1520/JFS13776 J

Herraiz, T., \& Chaparro, C. (2005). Human Monoamine Oxidase Enzyme Inhibition by Coffee and Beta-Carbolines Norharman and Harman Isolated from Coffee. Biochemical Biophysical Research Communications, 326, 378-386.

Himmelhoch, J. (1995). Monoamine Oxidase Inhibitors. In H. I. Kaplan, \& B. J. Sadock (Eds.), Comprehensive Textbook of Psychiatry (Vol. 2, 6th Ed., pp. 2038-2058). Philadelphia: Lippincott, Williams \& Wilkins.

Huang, L., Lu, C., Sun, Y., Mao, F., Luo, Z., Su, T., Jiang, H., Shan, W., \& Li, X. (2012). Multitarget-Directed Benzylideneindanone Derivatives: Anti- $\beta$-Amyloid (A $\beta$ ) Aggregation, Antioxidant, Metal Chelation, and Monoamine Oxidase B (MAO-B) Inhibition Properties against Alzheimer's Disease. Journal of Medicinal Chemistry, 55, 8483-8492. https://doi.org/10.1021/jm300978h

Hughes, W. (2001). Clinical Pharmacy. In J. Hughes, R. Donnelly \& G. James-Chatgilaou (Eds.), A Practical Approach (2nd ed., p. 164). South Yarra: Macmillan Publishers Australia Pty Ltd.

Jossan, S. S., Ekblom, J., Aquilonius, S. M., \& Oreland, L. (1994). Monoamine Oxidase-B in Motor Cortex and Spinal Cord in Amyotrophic Lateral Sclerosis Studied by Quantitative Autoradiography. Journal of Neural Transmission, 41, 243-248.

Jouvent, R., Le Houezec, J., Payan, C., Mikkelsen, H., Fermanian, J., Millet, V., \& Dufour, H. (1998). Dimensional Assessment of Onset of Action of Antidepressants: A Comparative Study of Moclobemide vs. Clomipramine in Depressed Patients with Blunted Affect and Psychomotor Retardation. Psychiatric Research, 79, 267-275.

https://doi.org/10.1016/S0165-1781(98)00046-8 
Kan, J. P., Mouget-Goniot, C., Worms, P., \& Biziere, K. (1986). Effect of the Antidepressant Minaprine on Both Forms of Monoamine Oxidase in the Rat. Biochemical Pharmacology, 35, 973-978. https://doi.org/10.1016/0006-2952(86)90085-7

Katschnik, H., Murray, B., \& Buller, R. (1997). The International Multicenter Clinical Trial Group on Moclobemide in Social Phobia. Moclobemide in Social Phobia. A Double-Blind, Placebo-Controlled Clinical Study. European Archives of Psychiatry and Clinical Neuroscience, 247, 71-80.

Kennedy, B. P., Ziegler, M. G., Alford, M., Hansen, L. A., Thal, L. J., \& Masliah, E. (2003). Early and Persistent Alterations in Prefrontal Cortex MAO A and B in Alzheimer's Disease. Journal of Neural Transmission (Vienna), 110, 789-801.

Kettler, R., Da Prada, M., \& Burkard, W. P. (1990) Comparison of Monoamine Oxidase-A Inhibition by Moclobemide in Vitro and ex Vivo in Rats. Acta Psychiatrica Scandinavica, 82, 101-102. https://doi.org/10.1111/j.1600-0447.1990.tb05348.x

Killen, J. D., Fortmann, S. P., Murphy Jr., G. M., Hayward, C., Fongm D., Lowenthal, K., Bryson, S. W., Killen D. T., \& Schatzberg, A. F. (2010). Failure to Improve Cigarette Smoking Abstinence with Transdermal Selegiline + Cognitive Behavior Therapy. Ad diction, 105, 1660-1668. https://doi.org/10.1111/j.1360-0443.2010.03020.x

Kimball, R. W., Friedman, A. P., \& Vallejo, E. (1960). Effect of Serotonin in Migraine Patients. Neurology, 10, 107-111. https://doi.org/10.1212/WNL.10.2.107

Kline, N. S., \& Cooper, T. B. (1980). Monoamine Oxidase Inhibitors as Antidepressants. In F. Hoffmeister, \& G. Stille (Eds.), Psychotrophic Agents (pp. 369-397). Weinheim: Springer-Verlag. https://doi.org/10.1007/978-3-642-67538-6_17

Kline, N.S. (1970). Monoamine Oxidase Inhibitors: An Unfinished, Picturesque Tale. In F. J. Ayd, \& B. Blackwell (Eds.), Discoveries in Biological Psychiatry (pp. 194-214). Philadelphia: Lippincott.

Knoll, J., \& Magyar, K. (1972). Some Puzzling Effects of Monoamine Oxidase Inhibitors. Advances in Biochemical Psychopharmacology, 5, 393-408.

Knudsen-Gerber, D. S. (2011). Selegiline and Rasagiline: Twins or Distant Cousins? Consultant Pharmacist, 26, 48-51. https://doi.org/10.4140/TCP.n.2011.48

Kok, L. P., \& Tsoi, W. F. (1995). A Controlled Double-Blind Trial of Moclobemide and Imipramine in the Treatment of Depression. Singapore Medical Journal, 36, 38-40.

Kong, P., Zhang, B., Lei, P., Kong, X., Zhang, S., Li, D., \& Zhang, Y. (2015). Neuroprotection of MAO-B Inhibitor and Dopamine Agonist in Parkinson Disease. International Journal of Clinical and Experimental Medicine, 8, 431-439.

Korenchuk, S., Lehr, J. E., Mclean, L., Lee, Y. G., Whitney, S., Vessella, R., Lin, D. L., \& Pienta, K. J. (2001). VCaP, a Cell-Based Model System of Human Prostate Cancer. In-Vivo, 15, 163-168.

Kragh-Sorensen, P. (1993). Randomized, Double-Blind, Parallel, Multi-Centre Study of Moclobemide vs. Clomipramine in Depressive Patients in General Practice. Eur Neuropsychopharmacology, 3, 359. https://doi.org/10.1016/0924-977X(93)90143-A

Krishnan, K. R. R. (2013) Monoamine Oxidase Inhibitors. In A. F. Schatzberg, \& C. B. Nemeroff (Eds.), Essentials of Clinical Psychopharmacology (pp. 119-136). Arlington: American Psychiatric Publishing.

Lamensdorf, I., Porat, S., Simantov, R., \& Finberg, J.P. (1999) Effect of Low-Dose Treatment with Selegiline on Dopamine Transporter (DAT) Expression and Amphetamine-Induced Dopamine Release in Vivo. British Journal of Pharmacology, 126, $997-$ 1002. https://doi.org/10.1038/sj.bjp.0702389

Larsen, J. K., \& Rafaelsen, O. J. (1980). Long-Term Treatment of Depression with Isocarboxazide. Acta Psychiatrica Scandinavica, 62, 456-463. 
https://doi.org/10.1111/j.1600-0447.1980.tb00634.x

Larsen, J. K., Gjerris, A., Holm, P., Andersen, J., Bille, A., Christensen, E. M., Høyer, E., Jensen, H., Mejlhede, A., Langargergaard, A., Laursen, A. L., Nilakantan, B., Olafsson, K., Severin B., \& Rafaelsen, O. J. (1991). Moclobemide in Depression: A Randomized Multicentre Trial against Isocarboxazide and Clomipramine Emphasizing Atypical Depression. Acta Psychiatrica Scandinavica, 84, 564-570. https://doi.org/10.1111/j.1600-0447.1991.tb03196.x

Laux, G., Volz, H. P., \& Möller, H. J. (1995). Newer and Older Monoamine Oxidase Inhibitors. A Comparative Profile. CNS Drugs, 3, 145-158. https://doi.org/10.2165/00023210-199503020-00006

Lecrubier, Y., \& Guelfi, J. D. (1990). Efficacy of Reversible Inhibitors of Monoamine Oxidase A in Various Forms of Depression. Acta Psychiatrica Scandinavica, 82, 18-23. https://doi.org/10.1111/j.1600-0447.1990.tb05319.x

Lecrubier, Y., Pedarriosse, A.-M., Payan, C., Schmid-Burgk, W., \& Stabl, M. (1995). Moclobemide vs. Clomipramine in Nonmelancholic, Nonpsychotic Major Depression. A Study Group. Acta Psychiatrica Scandinavica, 92, 260-265.

https://doi.org/10.1111/j.1600-0447.1995.tb09580.x

Lee, H. T., Choi, M. R., Doh, M. S., Jung, K. H., \& Chai, Y. G. (2013). Effects of the Monoamine Oxidase Inhibitors Pargyline and Tranylcypromine on Cellular Proliferation in Human Prostate Cancer Cells. Oncology Reports, 30, 1587-1592.

Lee, H. T., Jung, K. H., Kim, S. K., Choi, M. R., \& Chai, Y. G. (2012). Effects of Pargyline on the Cellular Proliferation in Human Breast Cancer Cells. Molecular \& Cellular Toxicology, 8, 393-399. https://doi.org/10.1007/s13273-012-0048-y

Li, Y., Qiang, X., Luo, L., Li, Y., Xiao, G., Tan, Z., \& Deng, Y. (2016). Synthesis and Evaluation of 4-Hydroxyl Aurone Derivatives as Multifunctional Agents for the Treatment of Alzheimer's Disease. Bioorganic \& Medicinal Chemistry, 24, 2342-2351. https://doi.org/10.1016/j.bmc.2016.04.012

Liebowitz, M. R., Gorman, J. M., Fyer, A. J., \& Klein, D. F. (1985). Social Phobia. Review of a Neglected Anxiety Disorder. Archives of General Psychiatry, 42, 729-736. https://doi.org/10.1001/archpsyc.1985.01790300097013

Lingjaerde, O., Jørgensen, J., Støren, R., Thomle, S., Wendt Raeder, L., Ruud, L. E., Schetelig, E., Sveaas, H. K., \& Leivestad, O. (1995). A Double-Blind Comparison of Moclobemide and Doxepin in Depressed General Practice Patients. Acta Psychiatrica Scandinavica, 92, 125-131. https://doi.org/10.1111/j.1600-0447.1995.tb09555.x

Lonnqvist, J., Sihvo, S., Syvälahti, E., \& Kiviruusu, O. (1994). Moclobemide and Fluoxetine in Atypical Depression: A Double-Blind Trial. Journal of Affective Disorders, 32, 169-177. https://doi.org/10.1016/0165-0327(94)90015-9

Loomer, H. F., Saunders, J. C., \& Kline, N. S. (1957). A Clinical and Pharmacodynamic Evaluation of Iproniazid as a Psychic Energizer. Psychiatric Research Reports of the American Psychiatric Association, 9, 129-141.

Lotufo-Neto, F., Trivedi, M., \& Thase, M. E. (1999). Meta-Analysis of the Reversible Inhibitors of Monoamine Oxidase Type A Moclobemide and Brofaromine for the Treatment of Depression. Neuropsychopharmacoogy, 20, 226-247.

https://doi.org/10.1016/S0893-133X(98)00075-X

Lum, C. T., \& Stahl, S. M. (2012). Opportunities for Reversible Inhibitors of Monoamine Oxidase-A (RIMAs) in the Treatment of Depression. CNS Spectrums, 17, 107-120. https://doi.org/10.1017/S1092852912000594

Magyar, K., \& Knoll, J. (1977). Selective inhibition of the "B Form" of Monoamine Oxidase. Polish Journal of Pharmacology and Pharmacy, 29, 233-246.

Mallinger, A. G., Frank, E., Thase, M. E., Barwell, M. M., Diazgranados, N., Luckenbaugh, 
D. A., \& Kupfer, D. J. (2009). Revisiting the Effectiveness of Standard Antidepressants in Bipolar Disorder: Are Monoamine Oxidase Inhibitors Superior? Psychopharmacology Bulletin, 42, 64-74.

Marks, J. (1965). Interactions Involving Drugs. In J. Marks, \& C. M. B. Pare (Eds.), Scientific Basis of Drug Therapy in Psychiatry (pp. 191-201), Oxford, New York: Pergamon Press. https://doi.org/10.1016/B978-0-08-011195-7.50026-5

Martini, A., Bonollo, L., Nicolis, F. B., Sega, R., Palermo, A., \& Braibanti, E. (1981). Effects of Caroxazone, a Reversible Monoamine Oxidase Inhibitor, on the Pressor Response to Intravenous Tyramine in Man. British Journal Clinical Pharmacology, 11, 605-610. https://doi.org/10.1111/j.1365-2125.1981.tb01177.x

Mashkovsky, M. D., \& Andrejeva, N. I. (1981). Pharmacological Properties of 2, 3, 3a, 4, 5, 6-hexahydro-8-methyl-1H-pyrazino [3, 2, 1-j, k] Carbazol Hydrochloride (Pirlindole), a New Antidepressant. Arzneimittel Forschung, 31, 75-79.

Mayersohn, M., \& Guentert, T. W. (1995). Clinical Pharmacokinetics of the Monoamine oxidase-A Inhibitor Moclobemide. Clinical Pharmacokinetics, 29, 292-332. https://doi.org/10.2165/00003088-199529050-00002

Meienberg, O., \& Amsler, F. (1996). Moclobemide in the Prophylactic Treatment of Migraine. A Retrospective Analysis of 44 Cases. European Neurology, 36, 109-110. https://doi.org/10.1159/000117221

Meienberg, O., \& Amsler, F. (1997). Preventive Treatment of Migraine and Chronic Tension Headache with Moclobemide. Praxis (Bern 1994), 86, 1107-1112.

Merikangas, K. R., \& Merikangas, J. R. (1995). Combination Monoamine Oxidase Inhibitor and Beta-Blocker Treatment of Migraine, with Anxiety and Depression. Biological Psychiatry, 38, 603-610. https://doi.org/10.1016/0006-3223(95)00077-1

Michelacci, S., \& Franchi, G. (1962). Treatment of Vascular Headaches. Minerva Medica, 53, 1521-1523.

Micó, J. A., Ardid, D., Berrocoso, E., \& Eschalier, A. (2006). Antidepressants and Pain. Trends in Pharmacological Sciences, 27, 348-354. https://doi.org/10.1016/j.tips.2006.05.004

Miller, R. B. (1963). Tranylcypromine and Cheese. British Medical Journal, 2, 1593. https://doi.org/10.1136/bmj.2.5372.1593-a

Miner, C. M., Conner, K. M., \& Davidson, J. R. T. (2000). New Treatments for Social Phobia. In U. Halbreich, \& S. A. Montgomery (Eds.), Pharmacotherapy for Mood, Anxiety, and Cognitive Disorders (pp. 389-398). Arlington: American Psychiatric Association Publishing.

Montgomery, S. A., Baldwin, D. S., Priest, R. G, Steinert, J., Patel, A., Herrington, R. N., \& Livingston, H.M. (1991) Minaprine and Dose Response in Depression. An Investigation of Two Fixed Doses of Minaprine Compared with Imipramine. Pharmacopsychiatry, 5, 168-174. https://doi.org/10.1055/s-2007-1014463

Mostert, S., Petzer, A., \& Petzer, J. P. (2016). Inhibition of Monoamine Oxidase by Benzoxathiolone Analogues. Bioorganic Medicinal Chemistry Letters, 26, 1200-1204. https://doi.org/10.1016/j.bmcl.2016.01.034

Mrazek, D. A., Hornberger, J. C., Altar, C. A., \& Degtiar, I. (2014). A Review of the Clinical, Economic, and Societal Burden of Treatment-Resistant Depression: 1996-2013. Psychiatric Services, 65, 977-987. https://doi.org/10.1176/appi.ps.201300059

Nair, N. P., Ahmed, S. K., \& Kin, N. M. (1993). Biochemistry and Pharmacology of Reversible Inhibitors of MAO-A Agents: Focus on Moclobemide. Journal of Psychiatry and Neurosciences, 18, 214-225.

Naoi, M., Maruyama, W., \& Inaba-Hasegawa, K. (2012). Type A and B Monoamine Oxi- 
dase in Age-Related Neurodegenerative Disorders: Their Distinct Roles in Neuronal Death and Survival. Current Topics in Medicinal Chemistry, 12, 2177-2188. https://doi.org/10.2174/156802612805219950

Naoi, M., Maruyama, W., Inaba-Hasegawa, K., \& Akao, Y. (2011). Type A Monoamine Oxidase Regulates Life and Death of Neurons in Neurodegeneration and Neuroprotection. International Review of Neurobiology, 100, 85-106. https://doi.org/10.1016/B978-0-12-386467-3.00005-4

Natoli, J. L., Manack, A., Dean, B., Butler, Q., Turkel, C. C., Stovner, L. \& Lipton, R. B. (2010). Global Prevalence of Chronic Migraine: A Systematic Review. Cephalalgia, 30, 599-609. https://doi.org/10.1111/j.1468-2982.2009.01941.x

Norman, T. R., Chamberlain, K. G., \& French, M. A. (1987). Platelet Monoamine Oxidase: Low Activity in Cigarette Smokers. Psychiatry Research, 20, 199-205.

https://doi.org/10.1016/0165-1781(87)90079-5

Norman, T. R., Chamberlain, K. G., French, M. A., \& Burrows, G. D. (1982). Platelet Monoamine Oxidase Activity and Cigarette Smoking. Journal of Affective Disorders, 4, 73-77. https://doi.org/10.1016/0165-0327(82)90021-0

Noyes Jr., R., Moroz, G., Davidson, J. R., Liebowitz, M. R., Davidson, A., Siegel, J., Bell, J., Cain, J. W., Curlik, S. M., Kent, T. A., Lydiard, R. B., Mallinger, A. G., Pollack, M. H., Rapaport, M., Rasmussen, S.A., Hedges, D., Schweizer, E., \& Uhlenhuth, E. H. (1997). Moclobemide in Social Phobia: A Controlled Dose-Response Trial. Journal of Clinical Psychopharmacology, 17, 247-254. https://doi.org/10.1097/00004714-199708000-00002

Oreland, L., \& Gottfries, C. G. (1986). Brain and Brain Monoamine Oxidase in Aging and in Dementia of Alzheimer's Type. Progress in Neuro-Psychopharmacology \& Biological Psychiatry, 10, 533-540. https://doi.org/10.1016/0278-5846(86)90023-0

Oreland, L. (1991). Monoamine Oxidase, Dopamine and Parkinson's Disease. Acta Neurologica Scandinavica, 136, 60-65. https://doi.org/10.1111/j.1600-0404.1991.tb05021.x

Oreland, L., Fowler, C. J., \& Schalling, D. (1981). Low Platelet Monoamine Oxidase Activity in Cigarette Smokers. Life Sciences, 29, 2511-2518. https://doi.org/10.1016/0024-3205(81)90706-2

Pallanti, S., Quercioli, L., \& Hollander, E. (2004). Social Anxiety in Outpatients with Schizophrenia. A Relevant Cause of Disability. American Journal of Psychology, 161, 53-58. https://doi.org/10.1176/appi.ajp.161.1.53

Pande, A. C., Birkett, M., Fechner-Bates, S., Haskett, R. F., \& Greden, J. F. (1996). Fluoxetine versus Phenelzine in Atypical Depression. Biological Psychiatry, 40, 10171020. https://doi.org/10.1016/0006-3223(95)00628-1

Parkinson Study Group (1993). Effects of Tocopherol and Deprenyl on the Progression of Disability in Early Parkinson's Disease. New England Journal of Medicine, 328, 176183. https://doi.org/10.1056/NEJM199301213280305

Parkinson Study Group (2004). A Controlled, Randomized, Delayed-Start Study of Rasagiline in Early Parkinson Disease. Archives of Neurology, 61, 561-566. https://doi.org/10.1001/archneur.61.4.561

Patat, A., Berlin, I., Durrieu, G., Armand, P., Fitoussi, S., Molinier, P., \& Caille, P. (1995). Pressor Effect of Oral Tyramine during Treatment with Befloxatone, a New Reversible Monoamine Oxidase-A Inhibitor, in Healthy Subjects. The Journal of Clinical Pharmacology, 35, 633-643. https://doi.org/10.1002/j.1552-4604.1995.tb05022.x

Phillip, M., Kohnen, R., \& Benkert, O. (1993). A Comparison Study of Moclobemide and Doxepin in Major Depression with Special Reference to Effects on Sexual Dysfunction. International Clinical Psychopharmacology, 7, 149-153.

https://doi.org/10.1097/00004850-199300730-00005 
Pirildar, S., Sezgin, U., Elbi, H., Uyar, M., \& Zileli, B. (2003). A Preliminary Open-Label Study of Moclobemide Treatment of Pain Disorder. Psychopharmacology Bulletin, 37, 127-134.

Pray, W. S. (2007). Interactions between Nonprescription Products and Psychotropic Medications. US Pharmacist, 32, 12-15.

Rascol, O., Brooks, D. J., Melamed, E., Oertel, W., Poewe, W., Stocchi, F., \& Tolosa, E., LARGO Study Group (2005). Rasagiline as an Adjunct to Levodopa in Patients with Parkinson's Disease and Motor Fluctuations (LARGO, Lasting Effect in Adjunct Therapy with Rasagiline Given Once Daily, Study): A Randomised, Double-Blind, ParallelGroup Trial. The Lancet, 365, 947-954. https://doi.org/10.1016/S0140-6736(05)71083-7

Remick, R. A., \& Froese, C. (1990). Monoamine Oxidase Inhibitors: Clinical Review. Canadian Family Physician, 36, 1151-1155.

Rendenbach-Mueller, B., Schlecker, R., Traut, M., \& Weifenbach, H. (1994). Synthesis of Coumarins as Subtype-Selective Inhibitors of Monoamine Oxidase. Bioorganic Medicinal Chemistry Letters, 4, 1195-1198. https://doi.org/10.1016/S0960-894X(01)80328-0

Riederer, P., \& Laux, G. (2011). MAO-Inhibitors in Parkinson's Disease. Experimental Neurobiology, 20, 1-17. https://doi.org/10.5607/en.2011.20.1.1

Rimón, R., Jääskeläinen, J., Kaartinen, P., Kalli, A., Kilponen, E., Koskinen, T., Nikkilä, H., Pirttiperä, V., \& Seppälä, J. (1993). Moclobemide vs. Imipramine in Depressed Out-Patients: A Double Blind Multi-Centre Study. International Clinical Psychopharmacology, 7, 141-147. https://doi.org/10.1097/00004850-199300730-00004

Robakis, D., \& Fahn, S. (2015). Defining the Role of the Monoamine Oxidase-B Inhibitors for Parkinson's Disease. CNS Drugs, 29, 433-441. https://doi.org/10.1007/s40263-015-0249-8

Robbins, L., \& Lang, S. S. (2000). Headache Help: A Complete Guide to Understanding Headaches and the Medicines to Relieve Them (p. 162). Boston: Hughton Mifflin Harcourt.

Rossel, L., \& Moll, E. (1990). Moclobemide versus Tranylcypromine in the Treatment of Depression. Acta Psychiatrica Scandinavica, 360, 61-62. https://doi.org/10.1111/j.1600-0447.1990.tb05333.x

Ruggieri, S., Fabbrini, G., Bramante, L., De Pandis, F., Stocchi, F., Barbanti, P., Vacca, L., \& Manfredi, M. (1996). An Open Study with Reversible MAO-A Inhibitors in Complicated Parkinson's Disease. Advances in Neurology, 69, 595-598.

Ruggieri, S., Stocchi, F., Bramante, L., De Pandis, M. F., Barbato, L., Bolner, A., Berardelli, A., \& Manfredi, M. (1994). MAO-A Inhibitor Moclobemide Has a Sympatomatic Effect in Parkinson's Disease. Movement Disorders, 9, 72.

Sadock, B. J., Sadock, V. A., \& Sussman, N. (2014). Kaplan \& Sadock’s Pocket Handbook of Psychiatric Drug Treatment ( $5^{\text {th }}$ ed.). Philadelphia: Lippincott, Williams \& Wilkins.

Sandler, M., Glover, V., Ashford, A., \& Esmail A. (1980). The Inhibition of Tyramine Oxidation and the Tyramine Hypertensive Response ("Cheese Effect") May Be Independent Phenomena. Journal of Neural Transmission, 48, 241-247. https://doi.org/10.1007/BF01250659

Sandyk, R., \& Iacono, R. P. (1987). Phenelzine in Migraine Headaches. International Journal Neuroscience, 35, 243. https://doi.org/10.3109/00207458708987135

Saunders, J. C., Roukema, R. W., Kline, N. S., \& Bailey S. D. (1959). Clinical Results with Phenelzine. American Journal Psychiatry, 116, 71-72. https://doi.org/10.1176/ajp.116.1.71

Saura, J., Luque, J. M., Cesura, A. M., Da Prada, M., Chan-Palay, V., Huber, G., Löffler, J., 
\& Richards, J. G. (1994). Increased Monoamine Oxidase B Activity in Plaque-Associated Astrocytes of Alzheimer Brains Revealed by Quantitative Enzyme Radioautography. Neuroscience, 62, 15-30. https://doi.org/10.1016/0306-4522(94)90311-5

Saxena, P. R., \& Ferrari, M. D. (1992). From Serotonin Receptor Classification to the Antimigraine Drug Sumatriptan. Cephalalgia, 12, 187-196.

https://doi.org/10.1046/j.1468-2982.1992.1204187.x

Shapira, A, Bate, G., \& Kirkpatrick, P. (2005). Rasagiline. Nature Reviews of Drug Discovery, 4, 625-626. https://doi.org/10.1038/nrd1803

Shapira, A. H. (2011). Monoamine Oxidase B Inhibitors for the Treatment of Parkinson's Disease: A Review of Symptomatic and Potential Disease-Modifying Effects. CNS Drugs, 25, 1061-1071. https://doi.org/10.2165/11596310-000000000-00000

Schlecker, R., Schmidt, P., Thieme, P. C., Lenke, D., Teschendorf, H. J., Traut, M., Mueller, C., Hofmann, H. P., \& Kreiskott, H. (1984). Sulfonic Acid Esters of Hydroxycoumarins. German Offenlegungsschrift, DE3243158A1.

Schoerlin, M. P., \& Da Prada, M. (1990). Species-Specific Biotransformation of Moclobemide: A Comparative Study in Rats and Humans. Acta Psychiatrica Scandinavica, 82, 108-110. https://doi.org/10.1111/j.1600-0447.1990.tb05351.x

Shaikh, W., \& Fuls, K. (2009). Tranylcypromine Dependence and Withdrawal. Australian and New Zealand Journal of Psychiatry, 6, 580-581.

Sherif, F., Gottfries, C. G., Alafuzoff, I., \& Oreland, L. (1992). Brain Gamma-Aminobutyrate Aminotransferase (GABA-T) and Monoamine Oxidase (MAO) in Patients with Alzheimer's Disease. Journal of Neural Transmission-Parkinson's Disease and Dementia Section, 4, 227-240. https://doi.org/10.1007/BF02260906

Shorter, E. (2008). Before Prozac: The Troubled History of Mood Disorders in Psychiatry. Oxford: Oxford University Press.

Shoulson, I. (1998). DATATOP: A Decade of Neuroprotective Inquiry. Parkinson Study Group. Deprenyl and Tocopherol Antioxidative Therapy of Parkinsonism. Annals of Neurology, 44, S160-S166. https://doi.org/10.1002/ana.410440724

Shulman, K. I., Herrmann, N., \& Walker, S. E. (2013). Current Place of Monoamine Oxidase Inhibitors in the Treatment of Depression. CNS Drugs, 27, 789-797.

https://doi.org/10.1007/s40263-013-0097-3

Shvedov, V. I., Altukhova, L. B., Andreeva, N. I., Mashkovskii, M., \& Grinev, A. N. (1972). [Derivatives of pyrazino- and piperazino[1, 2-a] indole]. Khimiko Farmatsevticheskii Zhurnal, 6, 14-17. https://doi.org/10.1007/bf00771296

Silverstone, T., Abou-Saleh, M. T., Pathak, R., Lock, T., Bennie, E., Mohammed, Y., Chakravarti, S. K., Jauhar, P., Katona, C., Shamash, K., Khan, M. C., Livingston, M., Cahill, C., Sharma, V. K., Singh, V., Cookson, J., Sireling, L. I., Morgan, J., \& Suri, A. K. (1994). A Multicentre Comparative Trial of Moclobemide, Imipramine and Placebo in Major Depressive Disorder. International Clinical Psychopharmacology, 9, 109-113. https://doi.org/10.1097/00004850-199400920-00007

Simpson, G. M., Shih, J. C., Chen, K., Flowers, C., Kumazawa, T., \& Spring, B. (1999). Schizophrenia, Monoamine Oxidase Activity, and Cigarette Smoking. Neuropsychopharmacology, 20, 392-394. https://doi.org/10.1016/S0893-133X(98)00119-5

Singh, T., \& Williams, K. (2006). Atypical Depression. Psychiatry, 3, 33-39.

Siever, L. J., Uhde, T. W., \& Murphy, P. L. (1982). Possible Sub-Sensitization of Alpha 2-Adrenergic Receptors by Chronic Monoamine Oxidase Treatment in Psychiatric Patients. Psychiatric Research, 6, 293-302.

Son, S. Y., Ma, J., Kondou, Y., Yoshimura, M., Yamashita, E., \& Tsukihara, T. (2008). Structure of Human Monoamine Oxidase A at 2.2-A Resolution: The Control of Opening 
the Entry for Substrates/Inhibitors. Proceedings of the National Academy of Sciences of the United States of America, 105, 5739-5744.

https://doi.org/10.1073/pnas.0710626105

Sparks, D. L., Woeltz, V. M., \& Markesbery, W. R. (1991). Alterations in Brain Monoamine Oxidase Activity in Aging, Alzheimer's Disease, and Pick's Disease. Archives of Neurology, 48, 718-721. https://doi.org/10.1001/archneur.1991.00530190064017

Stabl, M., Biziére, K., Schmid-Burgk, W., \& Amrein, R. (1989). Review of Comparative Clinical Trials. Moclobemide vs Tricyclic Antidepressants and vs Placebo in Depressive States. Journal of Neural Transmission, 28, 77-89.

Stein, D. J., Cameron, A., Amrein, R., \& Montgomery, S. A. (1996). Moclobemide Social Phobia Clinical Study Group. Moclobemide Is Effective and Well Tolerated in the Long-Term Pharmacotherapy of Social Anxiety Disorder with or without Comorbid Anxiety Disorder. International Clinical Psychopharmacology, 11, 83-88.

Steinmeyer, E. M., Vorbach, E. U., \& Arnoldt, K. H. (1993). Efficacy and Safety of Moclobemide Compared with Maprotiline in Treatment of Major Depressive Disorder -A Double-Blind Multicenter Study with Parallel Groups. Pharmacopsychiatry, 26, 246-253. https://doi.org/10.1055/s-2007-1014362

Sternic, N., Kacar, A., Filipovic, S., Svetel, M., \& Kostic, V.S. (1998). The Therapeutic Effect of Moclobemide, a Reversible Selective Monoamine Oxidase A Inhibitor, in Parkinson's Disease. Clinical Neuropharmacology, 21, 93-96.

Strolin Benedetti, M., \&, Dostert, P. (1987) Overview of the Present State of MAO Inhibitors. Journal of Neural Transmission, 23, 103-119. https://doi.org/10.1007/978-3-7091-8901-6_7

Sun-Edelstein, C., Tepper, S. J., \& Shapiro, R. E. (2008). Drug-Induced Serotonin Syndrome: A Review. Expert Opinion in Drug Safety, 7, 587-596. https://doi.org/10.1517/14740338.7.5.587

Targum, S. D., Burch, D. J., Asgharnejad, M., Petersen, T., Gomeni, R., \& Fava, M. (2014). Use of Band-Pass Filter Analysis to Evaluate Outcomes in an Antidepressant Trial for Treatment Resistant Patients. European Neuropsychopharmacology, 8, 1188-1195. https://doi.org/10.1016/j.euroneuro.2014.06.003

Tedeshi, R. E., Tedeshi, D. H., Ames, P. L., Cook, L., Mattis, P. A., \& Fellow E. J. (1959). Some Pharmacological Observations on Tranylcypromine (SKF Trans-385), a Potent Inhibitor of Monoamine Oxidase. Proceedings of the Society for Experimental Biolology (New York), 102, 380-381. https://doi.org/10.3181/00379727-102-25256

Tetrud, J. W., \& Langston, J. W. (1989). The Effect of (-)Deprenyl (Selegiline) on the Natural History of Parkinson's Disease. Science, 245, 519-522. https://doi.org/10.1126/science.2502843

Thiery, J. P. (2002). Epithelial-Mesenchymal Transitions in Tumour Progression. Nature Reviews Cancer, 2, 442-454. https://doi.org/10.1038/nrc822

Thomas, S. J., Shin, M., McInnis, M. G., \& Bostwick, J. R. (2015). Combination Therapy with Monoamine Oxidase Inhibitors and Other Antidepressants or Stimulants: Strategies for the Management of Treatment-Resistant Depression. Pharmacotherapy, 35, 433-449. https://doi.org/10.1002/phar.1576

Tort, S., Urrútia, G., Nishishinya, M. B., \& Walitt, B. (2012). Monoamine Oxidase Inhibitors (MAOIs) for Fibromyalgia Syndrome. The Cochrane Database of Systematic Reviews, 4. https://doi.org/10.1002/14651858.CD009807

True, L., Coleman, I., Hawley, S., Huang, C. Y., Gifford, D., Coleman, R., Beer, T. M., Gelmann, E., Datta, M., Mostaghel, E., Knudsen, B., Lange, P., Vessella, R., Lin, D., Hood, L., \& Nelson, P. S. (2006). A Molecular Correlate to the Gleason Grading system for Prostate Adenocarcinoma. Proceedings of the National Academy of Sciences of the 
United States of America, 103, 10991-10996. https://doi.org/10.1073/pnas.0603678103

Umbarkar, P., Singh, S., Arkat, S., Bodhankar, S. L., Lohidasan, S., \& Sitasawad, S. L. (2015). Monoamine Oxidase-A Is an Important Source of Oxidative Stress and Promotes Cardiac Dysfunction, Apoptosis, and Fibrosis in Diabetic Cardiomyopathy. Free Radical Biology \& Medicine, 87, 263-273. https://doi.org/10.1016/j.freeradbiomed.2015.06.025

Varga, E., \& Tringer, L. (1967) Clinical Trial of a New Type of Promptly Acting Psychoenergetic Agent (Phenyl-isopropylmethyl-propinylamine $\mathrm{HCl}, \mathrm{E}-250)$. Acta Medica Hungarica, 23, 289-295.

Versiani, M, Amrein, R., \& Montgomery, S. A. (1997). Social Phobia: Long-Term Treatment Outcome and Prediction of Response-A Moclobemide Study. International Clinical Psychopharmacology, 12, 239-254.

https://doi.org/10.1097/00004850-199709000-00001

Versiani, M., Nardi, A. E., Mundim, F. D., Alves, A. B., Liebowitz, M. R., \& Amrein, R. (1992). Pharmacotherapy of Social Phobia. A Controlled Study with Moclobemide and Phenelzine. British Journal of Psychiatry, 161, 353-360.

https://doi.org/10.1192/bjp.161.3.353

Versiani, M., Nardi, A.E., Mundim, F. D., Pinto, S., Saboya, E., \& Kovacs, R. (1996). The Long-Term Treatment of Social Phobia with Moclobemide. International Clinical Psychopharmacology, 11, 83-88. https://doi.org/10.1097/00004850-199606003-00014

Versiani, M., Oggeru, U., Alterwain, P., Capponi, R., Dajas, F., Heinze-Martin, G., Marquez, C. A., Poleo, M.A., Rivero-Almanzor, L.E., Rossel, L., Schmid-Burgk, W., \& Ucha Udabe, R. (1989). A Double Blind Comparative Trial of Moclobemide vs. Imipramine and Placebo in Major Depressive Episodes. British Journal Psychiatry, 155, 72-77.

Villarinho, J. G., de Vargas Pinheiro, K., de Vargas Pinheiro, F., Oliveira, S. M., Machado, P., Martins, M. A., Bonacorso, H. G., Zanatta, N., Fachinetto, R., \& Ferreira, J. (2013). The Antinociceptive Effect of Reversible Monoamine Oxidase-A Inhibitors in a Mouse Neuropathic Pain Model. Progress in Neuro-Psychopharmacology \& Biochemical Psychiatry, 44, 136-142. https://doi.org/10.1016/j.pnpbp.2013.02.005

Villarinho, J. G., Oliveira, S. M., Silva, C. R, Cabreira, T. N., \& Ferreira, J. (2012). Involvement of Monoamine Oxidase B on Models of Postoperative and Neuropathic Pain in Mice. European Journal of Pharmacology, 690, 107-114.

https://doi.org/10.1016/j.ejphar.2012.06.042

Visfeldt, J. (1961) [Iproniazid Poisoning. A Fatal Case with Liver and Kidney Damage]. Ugeskrift for Læger, 123, 1727-1728.

Vogt, M. (1969). Release from Brain Tissue of Compounds with Possible Transmitter Function: Interaction of Drugs with These Substances. British Journal Pharmacology, 37, 325-337. https://doi.org/10.1111/j.1476-5381.1969.tb10570.x

Von Knorring, L., \& Oreland, L. (1985) Personality Traits and Platelet Monoamine Oxidase in Tobacco Smokers. Psychological Medicine, 15, 327-334. https://doi.org/10.1017/S0033291700023606

Weinberger, A. H., Reutenauer, E. L., Jatlow, P. I., O’Malley, S. S., Potenza, M. N., \& George, T.P . (2010). A Double-Blind, Placebo-Controlled, Randomized Clinical Trial of Oral Selegiline Hydrochloride for Smoking Cessation in Nicotine-Dependent Cigarette Smokers. Drug and Alcohol Dependence, 107, 188-195.

https://doi.org/10.1016/j.drugalcdep.2009.10.009

Wimbiscus, M., Kostenko, O., \& Malone D. (2010). MAO Inhibitors: Risks, Benefits, and Lore. Cleve Clinic Journal of Medicine, 77, 859-882.

https://doi.org/10.3949/ccjm.77a.09103 
Wise, R. A., \& Rompre, P. P. (1989). Brain Dopamine and Reward. Annual Review of Psychology, 40, 191-225. https://doi.org/10.1146/annurev.ps.40.020189.001203

Wouters, J. (1998). Structural Aspects of Monoamine Oxidase and Its Reversible Inhibition. Current Medicinal Chemistry, 5, 137-162.

Wu, J. B., Lin, T. P., Gallagher, J. D., Kushal, S., Chung, L. W., Zhau, H. E., Olenyuk, B. Z., \& Shih, J. C. (2015) Monoamine Oxidase A Inhibitor-Near-Infrared Dye Conjugate Reduces Prostate Tumor Growth. Journal of the American Chemical Society, 137, 2366-2374. https://doi.org/10.1021/ja512613j

Wu, J. B., Shao, C., Li, X., Li, Q., Hu, P., Shi, C., Li, Y., Chen, Y. T., Yin, F., Liao, C. P., Stiles, B. L., Zhau, H. E., Shih, J. C., \& Chung, L. W. (2014). Monoamine Oxidase A Mediates Prostate Tumorigenesis and Cancermetastasis. Journal of Clinical Investigation, 124, 2891-2908. https://doi.org/10.1172/JCI70982

Wu, M. Y., Esteban, G., Brogi, S., Shionoya, M., Wang, L., Campiani, G., Unzeta, M., Inokuchi, T., Butini, S., \& Marco-Contelles, J. (2016). Donepezil-Like Multifunctional Agents: Design, Synthesis, Molecular Modeling and Biological Evaluation. European Journal of Medicinal Chemistry, 121, 864-879.

Wyatt, R. J., Potkin, S. G., Bridge, T. P., Phelps, B. H., \& Wise, C. D. (1980). Monoamine Oxidase in Schizophrenia: An Overview. Schizophrenia Bulletin, 6, 199-207. https://doi.org/10.1093/schbul/6.2.199

Xu, S., Adisetiyo, H., Tamura, S., Grande, F., Garofalo, A., Roy-Burman, P., \& Neamati, N. (2015). Dual Inhibition of Survivin and MAOA Synergistically Impairs Growth of PTEN-Negative Prostate Cancer. British Journal of Cancer, 113, 242-251. https://doi.org/10.1038/bjc.2015.228

Yáñez, M., \& Viña, D. (2013). Dual Inhibitors of Monoamine Oxidase and Cholinesterase for the Treatment of Alzheimer Disease. Current Topic in Medicinal Chemistry, 13, 1692-1706. https://doi.org/10.2174/15680266113139990120

Youdim, M. B. (1975). Monoamine Oxidase. Its Inhibition. Modern Problems of Psychopsychiatry, 10, 65-88. https://doi.org/10.1159/000397920

Zarate Jr., C. A., Tohen, M., Baraibar, G., Kando, J. C., \& Mirin, J. (1995). Prescribing trends of Antidepressants in Bipolar Depression. Journal of Clinical Psychiatry, 56, 260-264.

Zeller, E. A., Barsky, J., Fouts, J. R., Kirchheimer, W. F., \& Van Orden, L. S. (1952). Influence of Isonicotinic Acid (INH) and 1-Isonicotinic-2-Isopropyl-Hydrazide (IIH) on Bacterial and Mammalian Enzymes. Experimentia, 8, 349-350. https://doi.org/10.1007/BF02174413

Zellner, M., Baurederm M., Rappoldm E., Bugert, P., Kotzailias, N., Babeluk, R., Baumgartner, R., Attems, J., Gerner, C., Jellinger, K., Roth, E., Oehler, R., \& Umlauf, E. (2012). Comparative Platelet Proteome Analysis Reveals an Increase of Monoamine Oxidase-B Protein Expression in Alzheimer's Disease but Not in Non-Demented Parkinson's Disease Patients. Journal of Proteomics, 75, 2080-2092.

https://doi.org/10.1016/j.jprot.2012.01.014

Zhao, H., Flamand, V., \& Peehl, D. M. (2009). Anti-Oncogenic and Pro-Differentiation Effects of Clorgyline, a Monoamine Oxidase A Inhibitor, on High Grade Prostate Cancer Cells. BMC Medical Genomics, 2, 55-69.

https://doi.org/10.1186/1755-8794-2-55

Zheng, H., Fridkin, M., \& Youdim, M. B. (2012). From Antioxidant Chelators to SiteActivated Multi-Target Chelators Targeting Hypoxia Inducing Factor, Beta-Amyloid, Acetylcholinesterase and Monoamine Oxidase A/B. Mini-Reviews in Medicinal Chemistry, 12, 364-370. https://doi.org/10.2174/138955712800493898 
Submit or recommend next manuscript to SCIRP and we will provide best service for you:

Accepting pre-submission inquiries through Email, Facebook, LinkedIn, Twitter, etc. A wide selection of journals (inclusive of 9 subjects, more than 200 journals)

Providing 24-hour high-quality service

User-friendly online submission system

Fair and swift peer-review system

Efficient typesetting and proofreading procedure

Display of the result of downloads and visits, as well as the number of cited articles Maximum dissemination of your research work

Submit your manuscript at: http://papersubmission.scirp.org/

Or contact ojd@scirp.org 